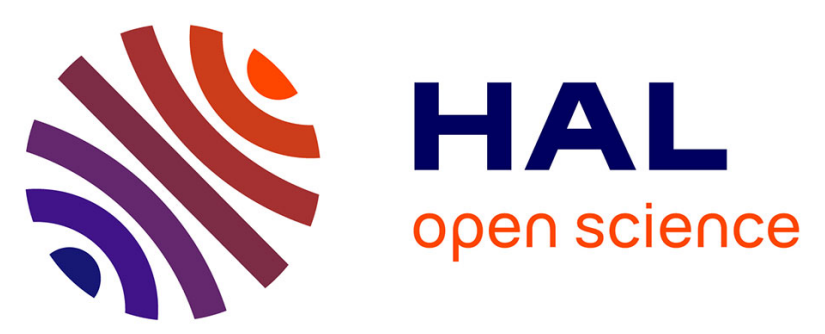

\title{
Angkorian Founders and Bronze Casting Skills: First Technical Investigation of the West Mebon Visnu
}

Aurélia Azéma, Pierre Baptiste, Jane Bassett, Francesca G Bewer, Ann Boulton, David Bourgarit, Manon Castelle, Laurence Garenne-Marot, Huot Samnang, Elsa Lambert, et al.

\section{To cite this version:}

Aurélia Azéma, Pierre Baptiste, Jane Bassett, Francesca G Bewer, Ann Boulton, et al.. Angkorian Founders and Bronze Casting Skills: First Technical Investigation of the West Mebon Visnu. Bulletin de l'Ecole française d'Extrême-Orient, 2018, 104 (1), pp.303 - 341. 10.3406/befeo.2018.6276 halshs02477437

\section{HAL Id: halshs-02477437 \\ https://shs.hal.science/halshs-02477437}

Submitted on 13 Feb 2020

HAL is a multi-disciplinary open access archive for the deposit and dissemination of scientific research documents, whether they are published or not. The documents may come from teaching and research institutions in France or abroad, or from public or private research centers.
L'archive ouverte pluridisciplinaire HAL, est destinée au dépôt et à la diffusion de documents scientifiques de niveau recherche, publiés ou non, émanant des établissements d'enseignement et de recherche français ou étrangers, des laboratoires publics ou privés. 


\section{Angkorian Founders and Bronze Casting Skills: First Technical Investigation of the West Mebon Visnu}

Aurélia Azéma, Pierre Baptiste, Jane Bassett, Francesca G. Bewer, Ann Boulton, David Bourgarit, Manon Castelle, Laurence Garenne-Marot, Huot Samnang, Elsa Lambert, Susan La Niece, Jeff Maish, Mathilde Mechling, B. Mille, Dominique Robcis, Donna K. Strahan, Annick Texier, Brice Vincent, Jeremy Warren, Ittai Weinryb, Jean-Marie Welter

\section{Citer ce document / Cite this document :}

Azéma Aurélia, Baptiste Pierre, Bassett Jane, Bewer Francesca G., Boulton Ann, Bourgarit David, Castelle Manon, Garenne-Marot Laurence, Samnang Huot, Lambert Elsa, La Niece Susan, Maish Jeff, Mechling Mathilde, Mille B., Robcis Dominique, Strahan Donna K., Texier Annick, Vincent Brice, Warren Jeremy, Weinryb Ittai, Welter Jean-Marie. Angkorian Founders and Bronze Casting Skills: First Technical Investigation of the West Mebon Visnu. In: Bulletin de I'Ecole française d'Extrême-Orient. Tome 104, 2018. pp. 303-341;

doi : https://doi.org/10.3406/befeo.2018.6276

https://www.persee.fr/doc/befeo_0336-1519_2018_num_104_1_6276

Fichier pdf généré le 07/01/2020 


\title{
Angkorian Founders and Bronze Casting Skills First Technical Investigation of the West Mebon Viṣnu
}

\author{
CAST:ING*
}

Keywords: Cambodia; Angkor; West Mebon; Viṣnu Anantaśāyin; bronze sculpture; lost-wax casting; technical study.

Mots-clés : Cambodge; Angkor; Mébon occidental; Viṣṇu Anantaśāyin; sculpture en bronze; fonte à la cire perdue; étude technique.

\section{Context of the study}

\subsection{The CAST:ING project}

Bronze and other copper-base alloys were used to produce sculpture all over the world since the 4th millennium BCE. Amongst the most costly and prestigious sculptural media, bronze is often chosen for particularly honored and sacred works. The complex sequence of procedures required to create a bronze sculpture reflects the specific technologies and skills available at the time. Close technical study of the work can therefore play a crucial role in expanding our understanding of the artisans and/or culture that fostered its creation. The scholarship of bronze sculpture from all cultures and periods has tremendously benefited in the last decades from such studies. Due to the growing quantity and complexity of technical research, together with the diversity of experts involved, a greater standardization of vocabulary

\footnotetext{
* Aurélia Azéma (Laboratoire de recherche des monuments historiques [LRMH]), Pierre Baptiste (Musée national des arts asiatiques - Guimet [MNAAG]), Jane Bassett (J. Paul Getty Museum), Francesca Bewer (Harvard Art Museums), Ann Boulton (Gilcrease Museum), David Bourgarit* (Centre de recherche et de restauration des musées de France [C2RMF]), Manon Castelle* (C2RMF), Laurence Garenne-Marot (Musée royal d'Afrique centrale), Huot Samnang (National Museum of Cambodia), Joachim Kreutner (Bayerisches Nationalmuseum), Elsa Lambert (C2RMF), Susan La Niece (British Museum), Jeff Maish (J. Paul Getty Museum), Mathilde Mechling (Université Sorbonne Nouvelle - Paris 3 / Universiteit Leiden), Benoît Mille (C2RMF), Dominique Robcis (C2RMF), Donna Strahan (Freer Gallery of Art and Arthur M. Sackler Gallery), Annick Texier (LRMH), Brice Vincent* (École française d'Extrême-Orient), Jeremy Warren (Independent scholar), Ittai Weinryb (Bard Graduate Center), Jean-Marie Welter (Independent scholar). [*: Lead authors.] The authors thank all the persons who have contributed, both scientifically and logistically, to the accomplishment of the technical study presented in this paper: at the Cambodian Ministry of Culture and Fine Arts, H.E. Phoeung Sackona; at the National Museum of Cambodia, Kong Vireak and the teams of the Metal Conservation Laboratory (Hem Kannitha, Suong Sokchea, Von Noeun) and the Sculpture Conservation Workshop (Chea Socheat, Phy Sokhoeun); at the APSARA National Authority, H.E. Sum Map, H.E. Hang Peou, H.E. Tan Boun Suy and Meas Rithyrathet; at the École française d'ExtrêmeOrient, Maric Beaufeist, Éric Bourdonneau, Ma Vonita, Bertrand Porte, Christophe Pottier and Isabelle Poujol; at the C2RMF, Isabelle Pallot-Frossard, Natalie Gandolfo and Jessica Legendre; and at the French Ministry of Culture, Bruno Favel. Many thanks also to Sébastien Clouet (Lettres Sorbonne Université), Meas Sreyneath (Université des Moussons - Manusastra), Martin Polkinghorne (Flinders University), Tol Marady (Department of Culture and Fine Arts, Kratie province), and Thierry Zéphir (MNAAG).
} 
and methodologies has increasingly become important in order to facilitate fruitful and meaningful comparison, interpretation and dissemination of data.

The aim of the CAST:ING project (Copper Alloy Sculpture Techniques and history: an International iNterdisciplinary Group) is to create a framework of shared protocols and vocabulary for technical studies that will aid advances in the understanding of bronze sculpture. The key outputs of the CAST:ING project will be an interactive set of Guidelines for the Technical Examination of Bronze Sculpture, to be published online by Getty Publications (late 2020); and an open-access website (www.cast-ing.org) to complement the publication that will serve as a much-needed forum for scholarly exchange of methods, data, and ideas related to the material study of bronze sculpture (e.g., production, conservation). The proposed standardization of terminologies and methodologies should help more consistent cataloguing, authentication, conservation and documentation of bronze sculpture, and is also critical for the development of a rigorous shared database model for the technical study of bronze sculpture.

The project is run by an international team of conservators, scientists, curators, art historians, historians, archaeologists, archaeometallurgists, and craftspeople, who are studying bronze production of different eras and cultures. The team gathered once a year since 2015 for discussions and handson workshops (launch meeting at the J. Paul Getty Museum, Los Angeles; bronze casting at the Coubertin Art Foundry, Saint-Rémy-lès-Chevreuse; chasing and engraving at the National Gallery of Art, Washington, D.C., and at the Centre de recherche et de restauration des musées de France, Paris). In January 2018, the meeting took place in Cambodia. Besides visits of ancient and modern Khmer foundries (Angkor Thom, Siem Reap, Udong), a preliminary technical investigation was carried out during one day and a half on the well-known but understudied bronze statue of the West Mebon Viṣnu (fig. 1), ${ }^{1}$ in close collaboration with the National Museum of Cambodia (NMC) and the Metal Conservation Laboratory (MCL). ${ }^{2}$ The main purpose was to test the Guidelines on a monumental bronze masterpiece produced by Angkorian founders, to track missing elements and to find out how a diversity of fields and disciplines may promote the emergence of new ideas.

The present paper aims at reporting on the preliminary technical results obtained and stressing the need for further study.

1. Unless otherwise stated, all pictures were taken by the authors at the NMC.

2. Only a selective bibliography on the West Mebon Viṣnu is proposed hereafter: Marchal 1936; Pelliot 1951: 11-12, 142-143; Malleret 1954: 302-303; Boisselier 1955: 278, pl. 106, 108; Boisselier 1956: 75-78, pl. 15; Groslier 1961: 129-130; Glaize 1963: 275-276, figs. 15, 106; Giteau 1965: 133, 134, fig. 73, pl. 15; Boisselier 1966: 324 n. 3, 325, 327, 338, pl. 57-2; Boisselier 1967: 276, 286, fig. 4; Dumarçay 1982: 100-103; Brand \& Chuch 1992: 68-71 (cat. 17), 72 (cat. 18); Jessup \& Zéphir 1997: 257-259 (cat. 68); Dalsheimer 2001: 243-244 (cat. 130), 245 (cat. 131); Dumarçay \& Royère 2001: 23, fig. 24; Penny et al. 2005: 498-499; Feneley 2006; Jessup 2006: 70 (cat. 45); Lobo 2006: 134-135 (cat. 51); Harris 2007: 48, 97-98, fig. 23; Bunker \& Latchford 2008: 45, figs. 4.18, 4.20; Feneley et al. 2008; Gerschheimer \& Vincent 2010: 118-119; Guy 2010a: 97-98, fig. 47; Guy 2010b; Oun \& Polkinghorne 2010; Bunker \& Latchford 2011: 228, 234, figs. 7.10a-b; Feneley 2013; Khun 2013: 9-11 (cat. 10); Vincent 2014a: 112, figs. 3.5.18a-b; Vincent 2014b: 27-29 (cat. 3.5); Feneley 2014; Feneley, Penny \& Fletcher 2016; Feneley 2017. 


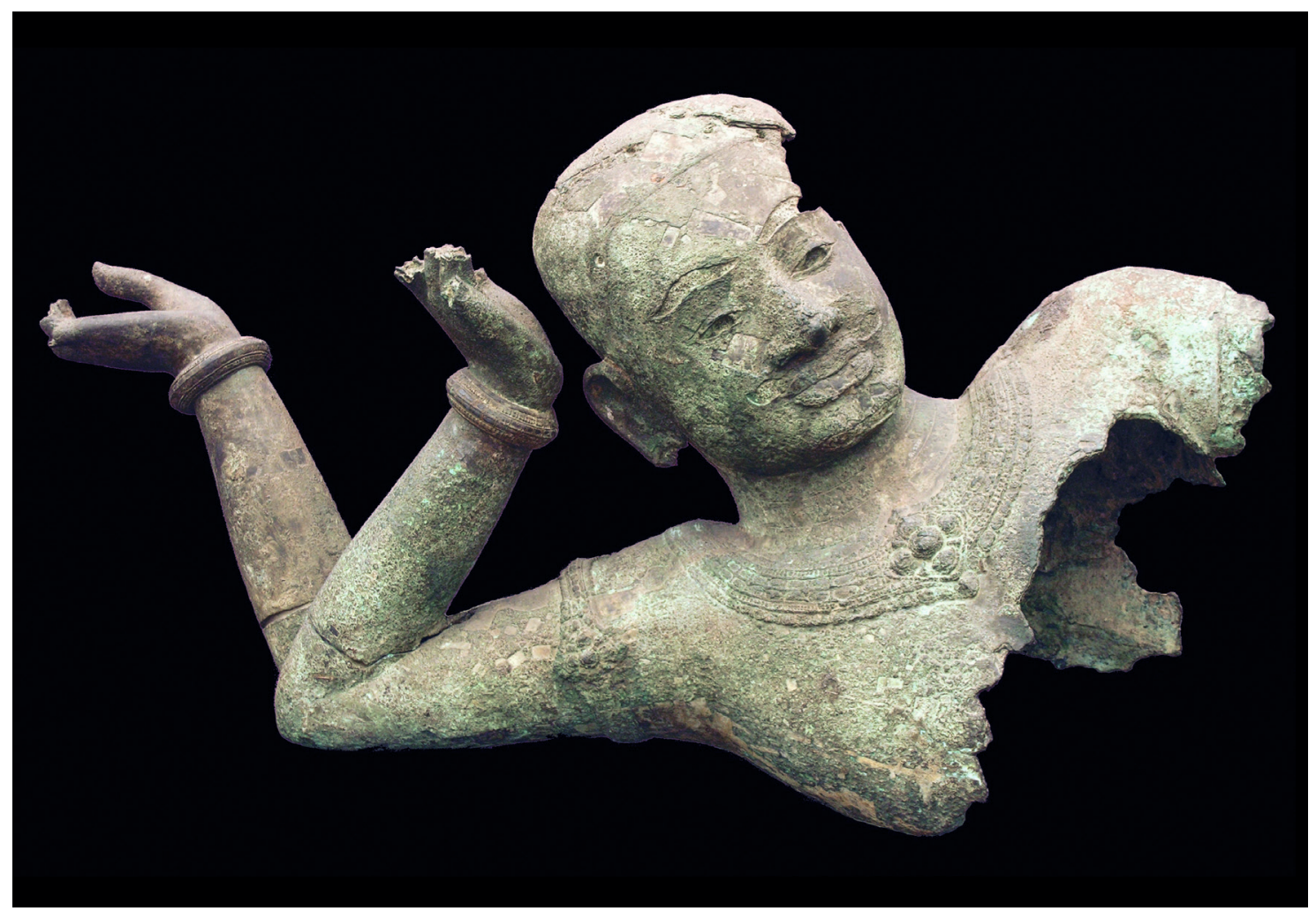

Fig. 1 - General view of the bust of the West Mebon Vișnu ( $g a$ 5387), 2nd half of 11th century. Bronze, L. 222 cm, H. 123 cm. Photo: P. Baptiste.

\subsection{The West Mebon Viṣnu}

\subsubsection{Context of discovery}

The discovery of the so-called "West Mebon Viṣnu", a fragmentary bronze statue of Viṣnu Anantaśāyin unearthed at the West Mebon temple in Angkor - generally dated on stylistic grounds to the second half of the 11th century -, was first detailed in the pages of the Bulletin de l'École française d'ExtrêmeOrient, as part of the "Chronique de l'année 1936". The text written by Henri Marchal was based on a monthly field report from Maurice Glaize, his EFEO colleague and successor at the head of the Angkor Conservation (1936-1946), and supplemented by the first published picture of the statue. ${ }^{3}$

The "official" discovery of the main fragments of the West Mebon Viṣnu took place between December 14th, 1936, and January 8th, 1937. ${ }^{4}$ Following information given by a villager from "Phum Kuk Thnot" named "ChhitLat", M. Glaize and a team of workers conducted excavation on the central

3. Marchal 1936, from $R C A$, December 1936. For a detailed description of the West Mebon temple, see for example Feneley, Penny \& Fletcher 2016. On the restoration project of the temple led between 2012 and 2018 by the EFEO and the APSARA National Authority, see also: https:// explore.psl.eu/fr/decouvrir/focus/lefeo-angkor-restauration-du-mebon-occidental.

4. JFCA, 13, May 1936-May 1937: 156-157, 159-169, 171, 175. 
platform of the temple, more precisely inside the so-called "western shaft", where the main fragments of the statue were found in a very wet environment, under approximately one meter of soil. A total of four large fragments, plus two fingers and smaller undetermined fragments, were unearthed and given a unique accession number when entering the storage of the Angkor Conservation in Siem Reap (fig. 2; acc. no. CA 3587).

This discovery was in fact preceded by a series of less spectacular, but no less relevant, metallic finds. During a visit to the West Mebon temple on January 29th, 1936, H. Marchal first received from gold diggers - then quite active inside the central pond of the monument - the left hand of a bronze statue originally found at the northwest angle of the central platform, close to its retaining wall (acc. no. CA 491, H. $33 \mathrm{~cm}$ ). ${ }^{5}$ As a consequence, fieldwork conducted by H. Marchal's ephemeral successor, Jacques Lagisquet (1936), and a team of workers took place between February 3rd and 20th, 1936, in order to search for other remaining parts of the corresponding bronze statue. It appears to have been rather successful as several supposed fragments of this statue were unearthed in the vicinity of the central platform, in addition to undetermined pieces of bronze and iron, namely: a fragment of ankle and another of bracelet (acc. no. CA 495 and CA 496); ${ }^{6}$ an additional fragment of bracelet (acc. no. CA 498); ${ }^{7}$ three undetermined fragments showing that the sculpture was hollow cast (acc. no. CA 499) $;{ }^{8}$ a finger and a fragment of garment or pedestal (acc. no. CA 500). ${ }^{9}$

Finally, still within the temple enclosure, two other finds of interest were made in the 1940s. On June 13th, 1940, the right hand of a bronze statue originally found near the central platform, inside the northern part of the pond, was brought to M. Glaize, for whom it could be associated with the first hand previously discovered, despite its smaller dimensions (acc. no. DB 587, H. $25 \mathrm{~cm}$ ). ${ }^{10}$ Then on May 22nd, 1944, as part of the first large-scale restoration of the monument (1942-1944), a new excavation was conducted on the central platform where the so-called "eastern shaft" was discovered, containing among other precious artifacts laying on a fine sand layer two copper fragments of tube or collar (acc. no. DB 631). ${ }^{11}$

5. JFCA, 12, March 1935-May 1936: 221-224 [drawing].

6. JFCA, 12, March 1935-May 1936: 230 [northwest angle of the central platform]: "à 2 mètres de l'emplacement où l'on a découvert la grande main en bronze on a trouvé un fragment de cheville en bronze qui provient sûrement, étant donné ses dimensions, de la même statue."

7. JFCA, 12, March 1935-May 1936: 231: "un morceau de bracelet qui doit provenir de la grande statue dont nous avons déjà des fragments."

8. JFCA, 12, March 1935-May 1936: 232-233 [northeast angle of the central platform]: "trois petits morceaux de bronzes [sic] susceptibles d'avoir appartenu à l'ensemble de la statue en bronze dont la recherche fait l'objet des fouilles à cet endroit. Cette statue aurait été composée sans doute d'un intérieur composé d'un remplissage de terre charbonneuse avec plaques de métal en revêtement."

9. JFCA, 12, March 1935-May 1936: 236, 239: "On a trouvé quelques débris de bronze qui doivent provenir de la statue que nous recherchons en particulier 1 doigt et un morceau de bronze rectiligne, qui serait soit un pli de vêtement, soit un fragment de piédestal."

10. JFCA, 15, April 1939-June 1942: 126-127: "il n'est pas impossible qu'elle provienne de la même statue, quoique paraissant légèrement plus petite que l'autre main, aux doigts allongés." 11. JFCA, 16, June 1942-December 1946: 179. 


\subsubsection{Previous conservation treatments and technical studies}

The various bronze fragments associated with the West Mebon Viṣnu were kept at the Angkor Conservation until November 1950, before being transferred to the NMC according to the will of Jean Boisselier, then curator of the institution (1949-1955). ${ }^{12}$ The statue was officially registered as part of its collections on December 1st, 1950. Accordingly, both accession and catalogue numbers were given: first, to the largest piece preserved, that is the head, torso, and right arms, named "bust" hereafter (acc. no. 5456 and cat. no. E.1229, with additional letters from $\mathrm{A}$ to $\mathrm{C}$ to distinguish the bust from the then mobile right forearms [later cat. no. E/I 30,17]); second, to 10 large fragments and 30 small ones (acc. no. 5457 and cat. no. E.1230, with additional letters from A to J only for the 10 large fragments [later cat. no. E/I 30,18]). The two hands also found at the West Mebon temple were sent before and entered the museum collections on August 25th, 1950 (right hand: acc. no. 4990 and cat. no. E.1116 [later cat. no. E/I 301,2]; left hand: acc. no. 4991 and cat. no. E.1117 [later E/I 701,17]1)

The reassembly of the right forearms onto the bust using cement - which is still visible - was certainly performed by the museum staff soon after December $1950 .{ }^{14}$ Also in the 1950 s, J. Boisselier sent three metal samples taken from the fragmentary statue (right forearms and left hip) to his EFEO colleague Louis Malleret in Saigon for elemental analysis. The results obtained through wet chemistry, certainly performed by the laboratory of the former "Office indochinois du riz", were then published by L. Malleret in 1954 in the Bulletin de la Société des Études Indochinoises, as part of an article precisely questioning the analysis of archaeological bronzes. ${ }^{15}$

For unexplained reasons, an additional fragment from the West Mebon temple - the ankle fragment mentioned above - only entered the museum collections in 1970, at the same time the metal collection of the Angkor Conservation was transferred from Siem Reap to Phnom Penh (acc. no. CA 7286). Finally, a total of 17 fragments (acc. no. E.1230) were restored in late first trimester 1972 at the "Laboratoire de restauration des métaux archéologiques", then relocated to the NMC and headed by the Cambodian metal conservator In Rom (1964-1974). ${ }^{16}$ Conservation techniques first developed by Albert France-Lanord at the "Laboratoire de Nancy" in France were routinely applied to bronze artifacts at that time, involving the use of materials such as epoxy resin, loose-weave fabric, wax or bedacryl. ${ }^{17}$

\footnotetext{
12. JFCA, 22, March-December 1950: 188-189.

13. Inventory files, acc. no. 5456 and 5457, 4990 and 4991 (NMC archives). The description of the 10 large fragments (cat. no. E.1230A-J) is reproduced in Jessup \& Zéphir 1997: 362 (cat. 68).

14. Inventory file, acc. no. 5456 (NMC archives): "3 fgts. remontés".

15. Malleret 1954: 302-303. In fact, already in 1936, M. Glaize sent a metal sample taken from the West Mebon Viṣnu to the EFEO office in Hanoi for the same purpose ( $R C A, 1936$ : "Nous vous envoyons par ailleurs un échantillon de matière, aux fins d'analyse."). However, no results from those analyses were found in the EFEO archives.

16. "Labo bronzes. Liste des pièces en bronze de provenances diverses restaurées et soignées de janvier 1972 à décembre 1973" (NMC archives): "E.1230", "Dix grands fragments numérotés et sept autres fragments non numérotés".

17. For more details on these conservation techniques and their theoretical elaboration, see Rolland 2017.
} 


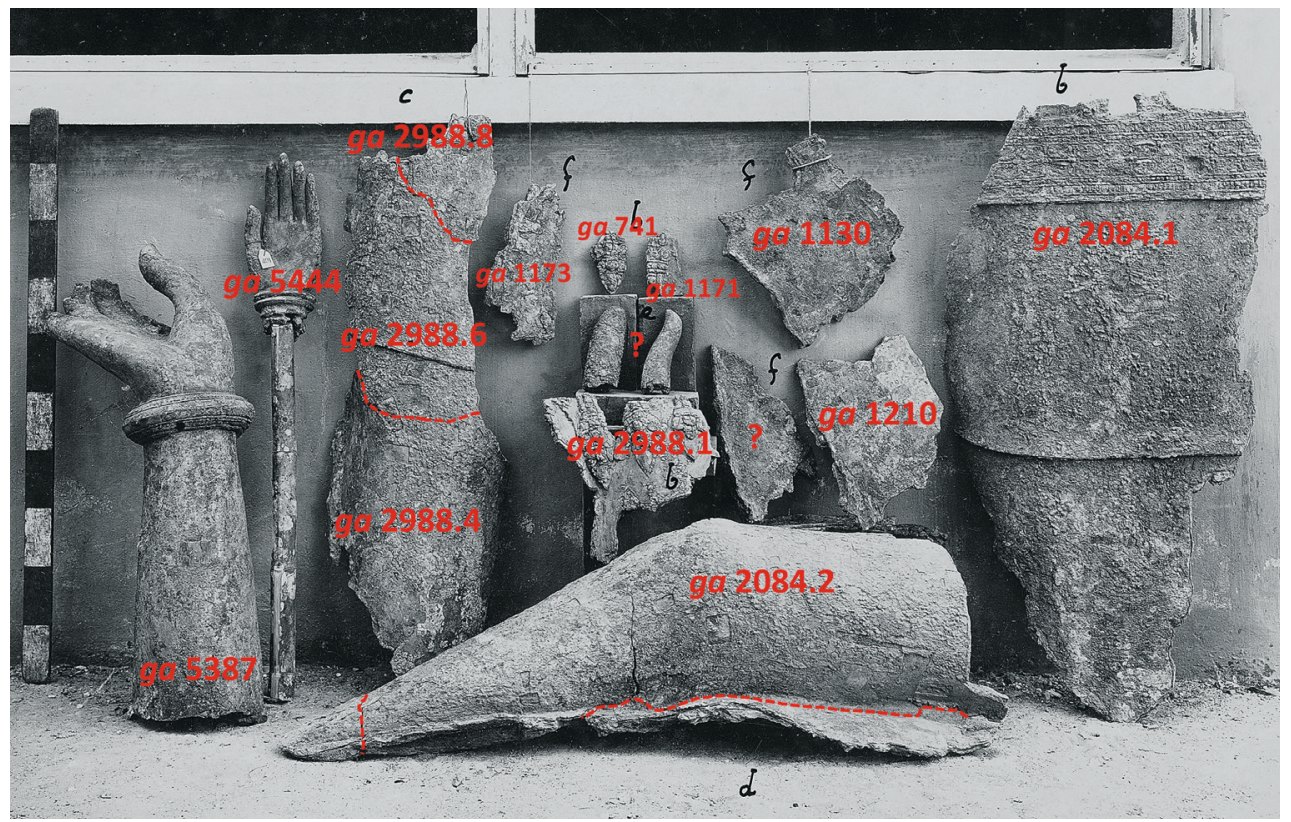

Fig. 2 - Main fragments of the West Mebon Viṣnu, plus a left hand of statue, as unearthed in 1936, with the NMC accession numbers (the red dotted lines indicate the current fragmentation state). Photo: EFEO, fonds Cambodge, ref. CAM13763.

After various curatorial displays within the museum galleries, as evidenced by archive pictures, and more recent travels for international exhibitions, ${ }^{18}$ the bust of the West Mebon Viṣnu now stands at the center of the exhibition room dedicated to the so-called "Baphuon style" of Khmer art (ca. 1010-1080 CE), whereas the two hands of statue are exhibited in the bronze gallery and all other fragments kept in the museum storage. Since 2005, Marnie Feneley (University of New South Wales) has been documenting this set of fragments with the help of comparative iconography and $3 \mathrm{D}$ visualization, in order to propose a digital reconstruction of the original bronze statue whose length is estimated over 6 meters. ${ }^{19}$ The last photogrammetric models of the main fragments were elaborated from pictures taken in December 2017. ${ }^{20}$

\subsubsection{Corpus under study}

As mentioned above, 10 large fragments and 30 small ones from the West Mebon Viṣnu entered the NMC on December 1950. Since then, however, at least the largest pieces of the statue have continued to follow a heavy fragmentation process, thus expanding the number of preserved fragments. Simple comparison of existing pieces with archive pictures taken at the time of the discovery clearly confirms this conservation issue (fig. 2).

18. Canberra in 1992 (Brand \& Chuch 1992); Paris, Washington, D.C., Tokyo, and Osaka in 1997-1998 (Jessup \& Zéphir 1997); Bonn, Berlin, and Zurich in 2006 (Lobo 2006).

19. Feneley 2006; Feneley et al. 2008; Feneley 2013, 2014; Feneley, Penny \& Fletcher 2016; Feneley 2017.

20. See for example: https://sketchfab.com/models/8987c7609b134749866a2960d1bc842b. 

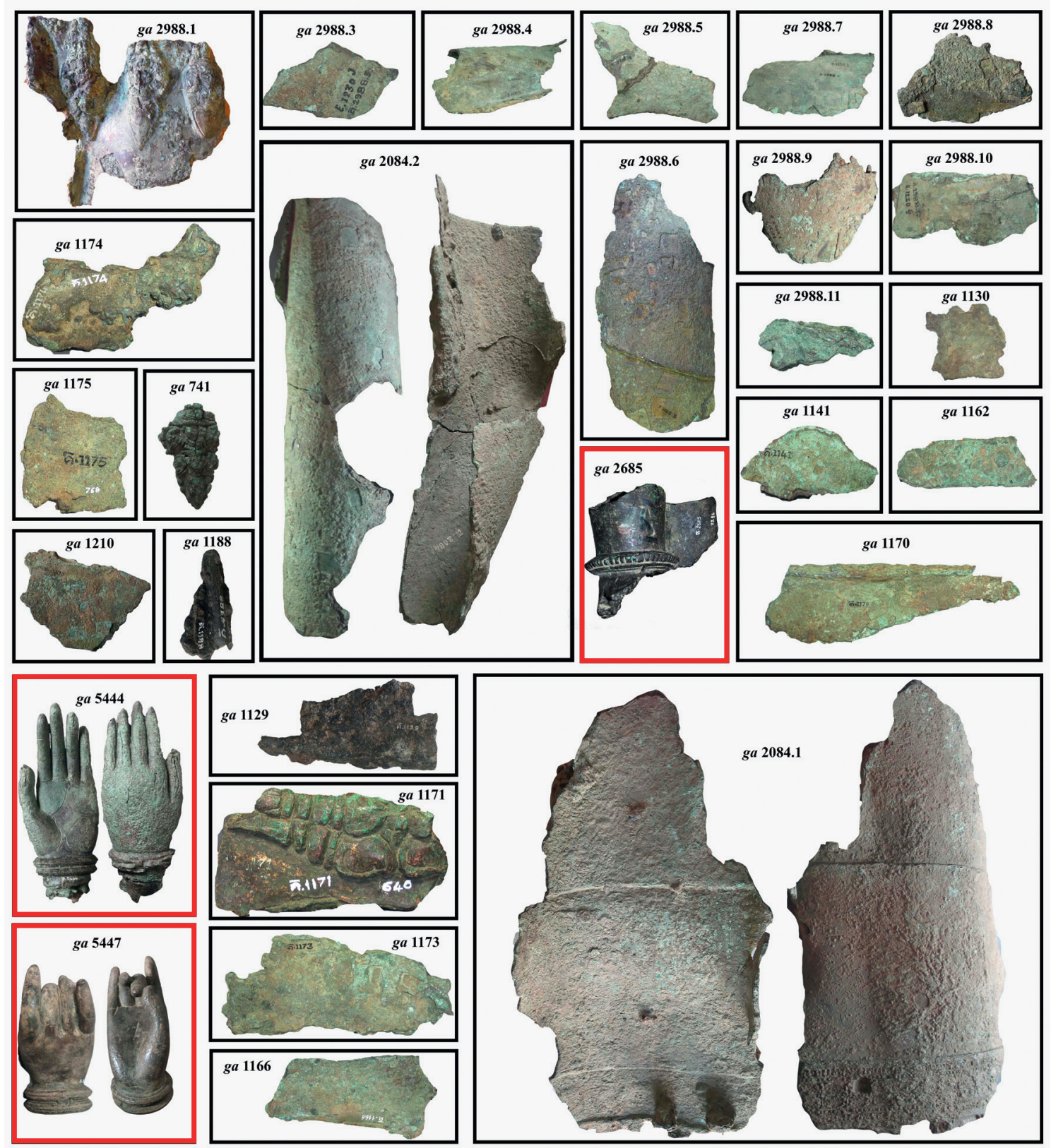

Fig. 3 - Main fragments of the West Mebon Vișṇu, plus two hands of statue and one ankle fragment, kept at the NMC. Photos: NMC and S. Clouet.

In addition to the bust (acc. no. ga 5387) and the left and right hands (respectively, acc. no. ga 5444 and ga 5447), only 26 fragments from the 1936 excavation were securely associated with the West Mebon Viṣnu (fig. 3). Among them are several large fragments already identified before, but, for some of them, now broken into several pieces: a fragment of left hip and thigh with sampot and belt (acc. no. ga 2084.1); three supposed 
fragments of right leg, including shin, knee and thigh (acc. no. ga 1170, ga 2084.2 and ga 2988.9); one fragment with pendants (acc. no. ga 2988.1); three fragments of thigh with sampot (acc. no. ga 2988.4, ga 2988.6 and ga 2988.8). Even described with more or less details in the JFCA or photographed, other smaller pieces are clearly missing - at least for now -, such as the two fingers, a thumb and a ring finger, mentioned above.

Finally, only recovered in June 2016 during a new excavation of the central platform of the West Mebon temple, an additional small bronze fragment, named "West Mebon 1" hereafter, entered the corpus of study. ${ }^{21}$ The latter is thus currently constituted of a total of 30 fragments (table 1). ${ }^{22}$ They vary much in size. The bust $\mathrm{ga} 5387$ is $222 \mathrm{~cm}$ long for $123 \mathrm{~cm}$ high, whereas the large fragments ga 2084.1 and ga 2988.4 reach $100 \mathrm{~cm}$ long, and the fragment ga 1170 reaches $94 \mathrm{~cm}$. Most of the other pieces are from a few centimeters to a few tens of centimeters.

\subsection{Operating conditions}

The twenty CAST:ING members, plus several observers, participating in the technical study on January 12th, 2018, were divided into four working groups. Along one hour and a half sessions, they investigated alternatively the bust and three batches of fragments, each including one of the large fragments mentioned above. Main tools at disposal were cameras, rulers, digital calipers, tape measures, flash lights, magnets (to detect iron items such as armatures and core pins), and binocular lenses. Two portable digital microscopes, one endoscope, and one handheld X-ray fluorescence device (for surface qualitative analysis) were also used.

The two hands ga 5444 and $g a 5447$, and the ankle fragment $g a 2685$, were briefly investigated later, respectively in May and July 2018, by a reduced team under the same operating conditions.

A total of 40 metal samples were drilled by D. Bourgarit and B. Vincent from the bust and a number of fragments, plus the two hands, during three campaigns (October 2013, July 2015, and May 2018). Bulk-metal analysis was then performed on the drillings at the C2RMF by ICP-AES, following a methodology specifically developed for ancient copper-alloy artifacts. ${ }^{23}$

Reassembly tests were carried out by the CAST:ING members during the January 2018 technical study, and then by the MCL team during the following months, by juxtaposing the different fragments. Additionally, with the help of the Sculpture Conservation Workshop, a plaster imprint was taken from one edge of the fragment ga 2084.2 and tested on the left shoulder of the statue.

21. This fragment was unearthed just below the surface, at the south of the central platform and against its sandstone masonry. It is temporarily kept at the EFEO center in Siem Reap (pers. comm. M. Beaufeist, June 2018).

22. To obtain the dimensions and weight of the corresponding fragments, the authors used the online catalogue of the NMC collections (available in Khmer and English): http://www.cambodiamuseum. info/.

23. Bourgarit \& Mille 2003. 


\section{Main results of the technical investigation}

\subsection{Toward a unique copper-base alloy for 11th-century bronze statuary}

The composition of the metal used to cast the West Mebon Viṣnu and the two hands ga 5444 and ga 5447 matches the composition of some other 11th-century Khmer bronze images (tables $2 \mathrm{a}-\mathrm{b}$ ). ${ }^{24}$ The alloy is in majority an unleaded tin bronze with about 8 to $13 \mathrm{wt} . \%$ tin and less than $0.3 \mathrm{wt} . \%$ lead (fig. $4 \mathrm{a}$ ). Some lead may be added up to a few percents, in particular for secondary casts used for repairs or assemblies. Main impurities are nickel (around $0.3 \mathrm{wt} . \%$ ), arsenic (0.2 wt.\%), and lead (0.1-0.3 wt.\%) (fig. 4b). Silver, antimony and cobalt are also present (around 0.02 to $0.05 \mathrm{wt} . \%$ ). The particularly low amounts of sulfur (less than $200 \mathrm{ppm}$ ) and zinc (less than $50 \mathrm{ppm}$ in most cases) should be stressed. Relatively low amounts of gold were measured as well, at least as compared with what was observed on some later 12th- and 13th-century Khmer bronzes. ${ }^{25}$ It must be added that the results are in agreement with the two analyses made in the early 1950s on the lower right forearm and the left hip, except for zinc for which large amounts were measured $(2 \mathrm{wt} . \%){ }^{26}$
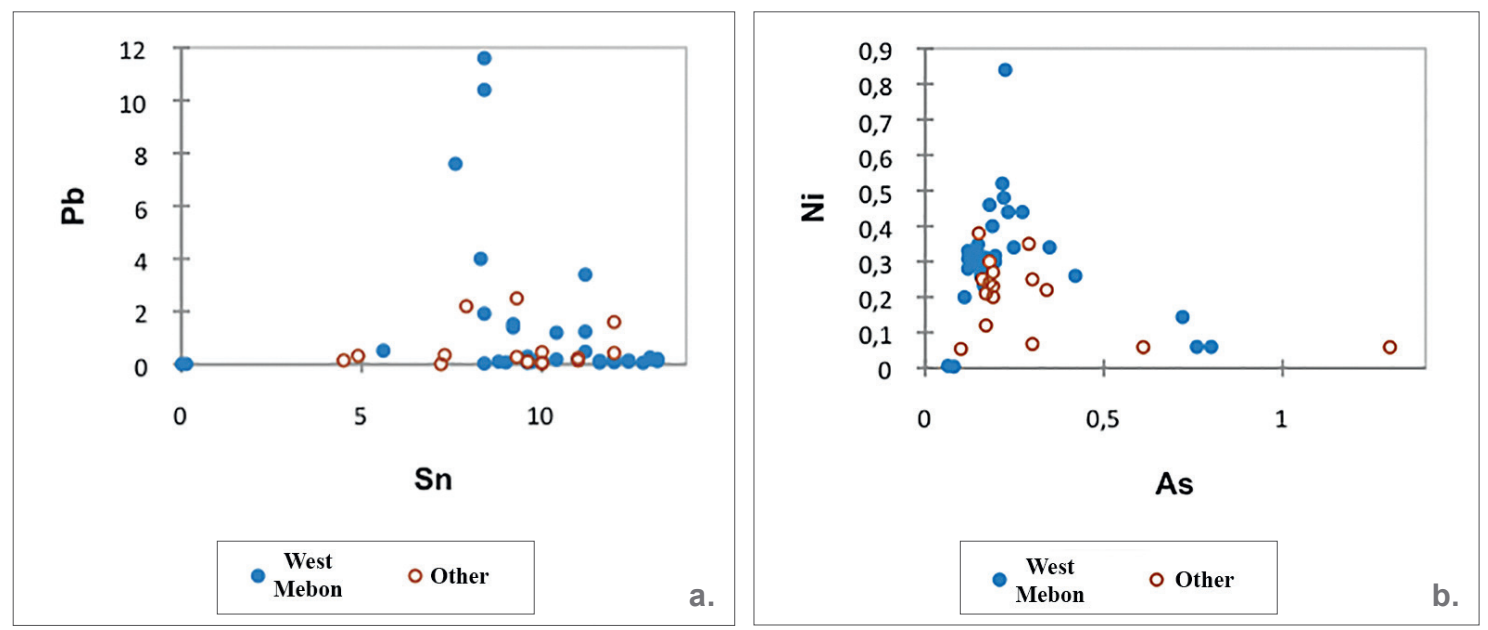

Fig. 4 - Binary plots showing the contents in various elements (wt.\%) of the metal of different parts and fragments of the West Mebon Viṣnu, the two hands ga 5444 and ga 5447, and a selection of 1611 th-century Khmer bronze statues (analysis by ICP-AES at the C2RMF): (a) lead $(\mathrm{Pb})$ versus tin $(\mathrm{Sn})$; (b) nickel (Ni) versus arsenic (As). Diagrams: D. Bourgarit.

The similarities of composition of most bronze statues selected may point to a unique workshop or at least to a unique production center, which

24. For comparative purpose, a corpus of 16 Hindu-Buddhist statues, all belonging to the "Baphuon" stylistic tradition and offering data from bulk-metal analysis was selected. From both Cambodian and Western museum collections, they were sampled and analyzed using the same operating conditions as those used for the West Mebon Viṣnu.

25. Bourgarit et al. 2003: 112-113, 118; Vincent 2012: 320-321, 326, 331-332.

26. Malleret 1954: 302-203. 


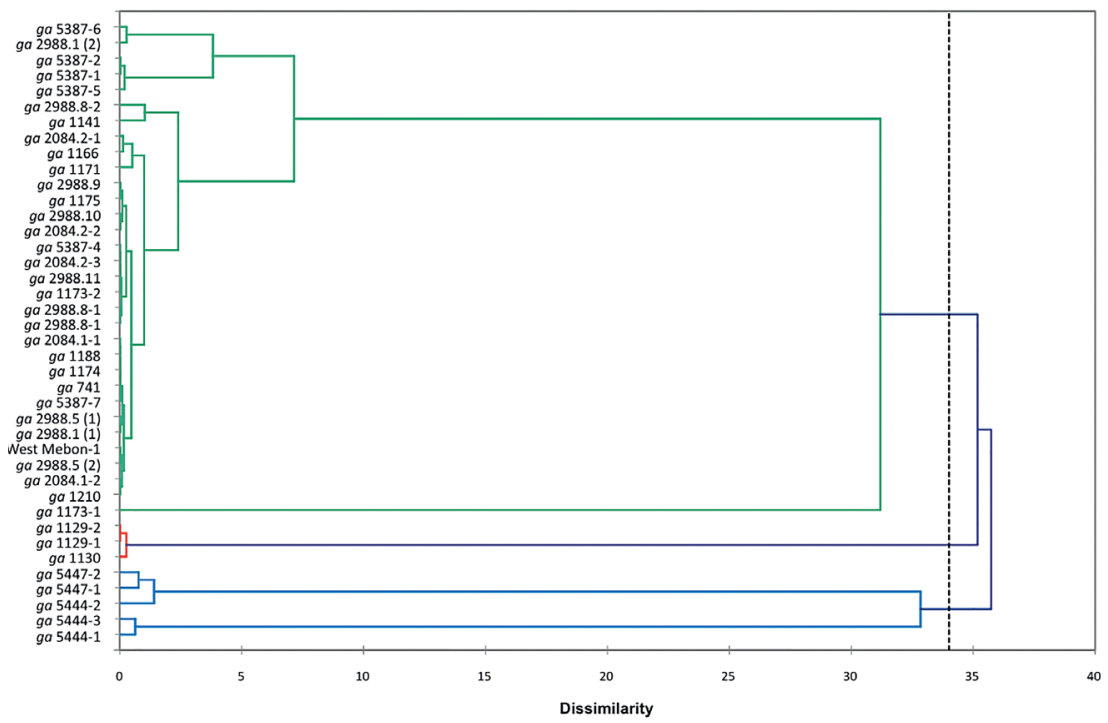

Fig. 5 - Grouping of different parts and fragments of the West Mebon Viṣnu, and the two hands ga 5444 and ga 5447, according to their metal composition. Clustering made on the 4 first components of a principal components analysis (PCA) carried out on 11 chemical elements (Ag, As, $\mathrm{Au}, \mathrm{Bi}, \mathrm{Co}, \mathrm{Fe}, \mathrm{Ni}, \mathrm{Pb}, \mathrm{Sb}, \mathrm{Se}, \mathrm{Sn}$ ). Dendrogram: D. Bourgarit.

is particularly relevant considering the now-confirmed activity of a royal foundry in Angkor during the 11th and 12th centuries. ${ }^{27}$ Later statues attributed to the so-called "Angkor Vat style" (ca. 1080-1175 CE) prove to be made of a different metal, namely, leaded tin bronze with low nickel. ${ }^{28}$ The similar patterns of impurities for all 11th-century statues selected, including the West Mebon Viṣnu, not only point to the same type of copper deposit being exploited, but also to the same type of lead. ${ }^{29}$ The latter is systematically strongly correlated with arsenic and antimony, in addition to the more common bismuth.

\subsection{The West Mebon bronze corpus: reassembly}

\subsubsection{The Vișnu Anantaśāyin and the other statues}

Although very similar, the metal compositions of the West Mebon finds may be sorted into several groups (fig. 5). The fragments of the Viṣnu Anantaśāyin statue constitute a quite homogenous ensemble, as further discussed below. The recently excavated fragment West Mebon 1 proves to be part of this first group. However, two outliers have to be discarded from the statue, namely,

27. Polkinghorne et al. 2014. The royal foundry located north of the Royal Palace in Angkor Thom is now under study as part of the research project LANGAU - Fondre pour le roi : étude archéométallurgique de l'atelier de bronziers du palais royal d'Angkor Thom (APSARA National Authority \& EFEO, 2016-2019, co-dir. B. Vincent \& H.E. Tan Boun Suy [until 2018]).

28. Vincent 2012: 315-317, 320.

29. It is out of the scope of this paper to address the issue of metal provenancing. This is one of the research objectives of the ongoing LANGAU project. 


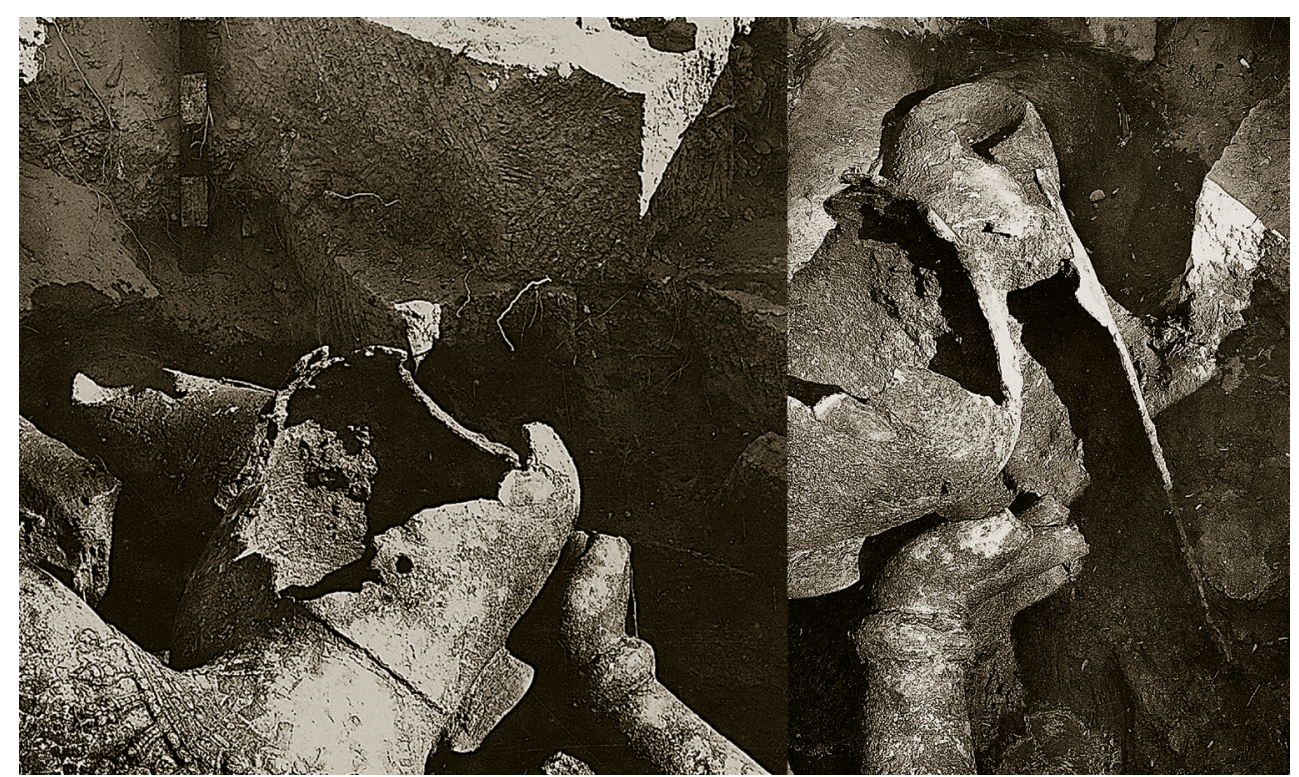

Fig. 6 - Details of the West Mebon Viṣnu during excavation showing the fragmentary right leg. Photos: EFEO, fonds Cambodge, ref. CAM13758-13759.

the fragments ga 1129 and $g a 1130$. The belonging of ga 1129 to the West Mebon bronze corpus may even be questioned.

The two hands ga 5444 and ga 5447 are associated with two distinct chemical patterns, both clearly differentiated from that of the Viṣnu (fig. 5). This would imply that the corresponding statue(s), of smaller size as mentioned above, have not been cast together with the Viṣnu. Additionally, the relatively large differences of composition between the two hands may point to two different sculptures and times of production. Yet the remnant of forearm attached to the hand ga 5444 is very similar in composition to the hand $g a 5447$. Given that the composition of $g a 5447$ is much closer to the Viṣnu composition than ga 5444, one may wonder whether the left hand ga 5444 is a later addition to the statue bearing the right hand $g$ a $5447 .{ }^{30}$

\subsubsection{The West Mebon Viṣnu: a complex "puzzle"}

The fragment $g a$ 2084.2, with other fragments, was for long attributed to the right leg of the West Mebon Viṣnu (fig. 6). As supported by physical measurements, however, this piece would rather be part of the missing left arm. The hole previously identified on the fragment $g a 2084.2$ as a missing knee shows, for instance, the same diameter as the supposed left forearms and the right forearms still on the bust (fig. 7). It is therefore clearly the junction of the left forearms at the level of the elbow. Additionally, tests using a plaster template have shown that the curvature of the fragment edge and the left shoulder perfectly match (figs. 8a-b).

30. The metal from $g a 5444$ is very peculiar with very low amounts of most impurities, including nickel and arsenic. 


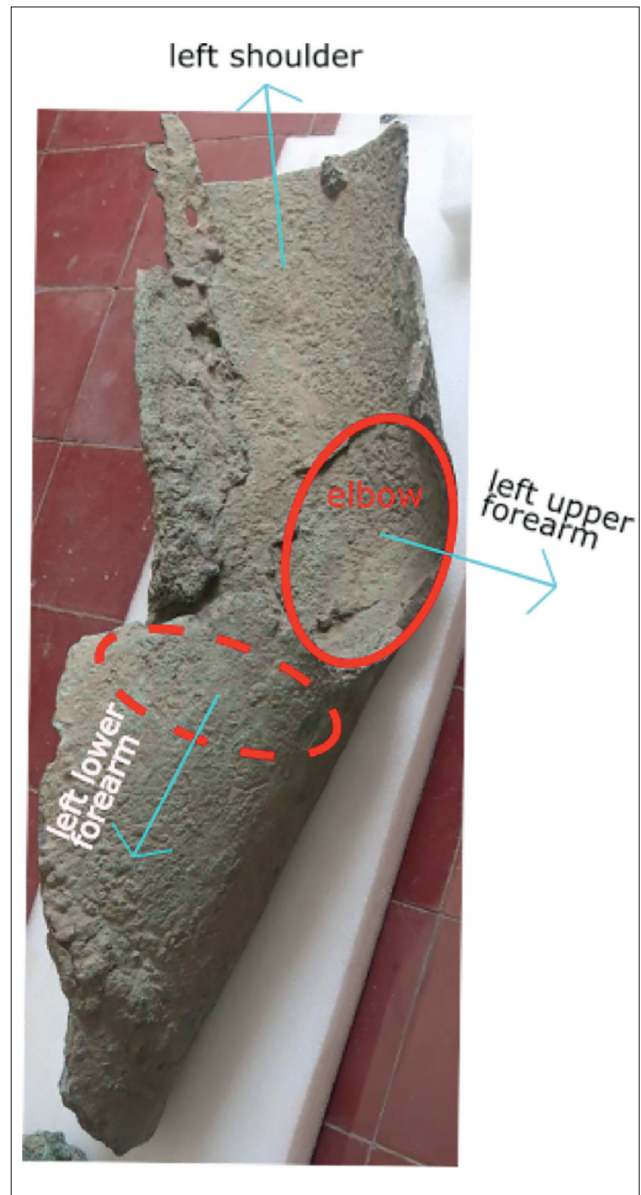

Fig. 7 - Left arm fragment ga 2084.2. The internal diameter of the hole featuring the elbow (red plain ellipse: D. $22 \mathrm{~cm}$ ) is similar to the one of the left lower forearm (red dotted ellipse).
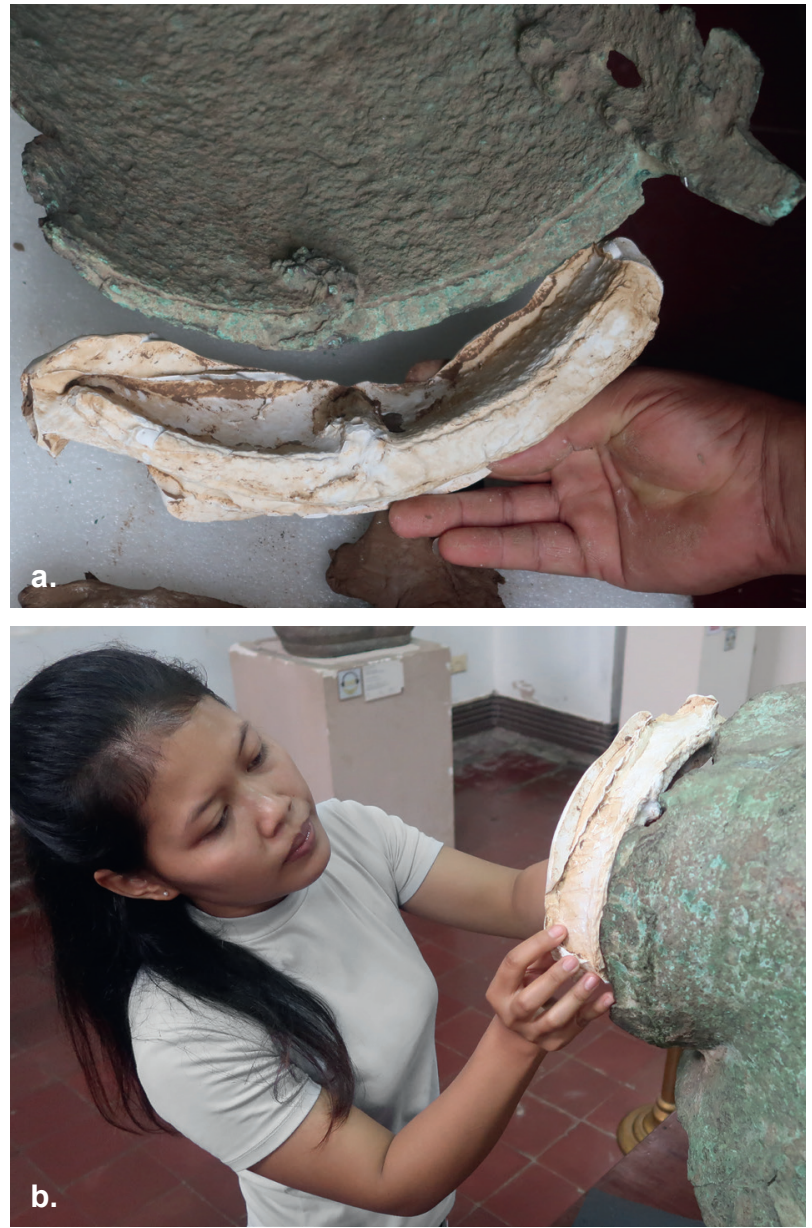

Fig. 8 - (a) Plaster imprint from one side of the left arm fragment ( $g a$ 2084.2); and (b) test of the template on the left shoulder ( $g a$ 5387).

Several other fragments were reassembled by visual examination. First, as mentioned before, the fragments ga 2988.4, ga 2988.6 and ga 2988.8 are the three parts of a large fragment of thigh with sampot broken after excavation (figs. 2 and 9a). Second, the newly identified left arm fragment ga 2084.2 was completed by the fragment ga 2988.9 (fig. 9b). Third, the fragments ga 1171, ga 2988.1, ga 2988.3, and perhaps ga 1173, are associated with the large fragment $\mathrm{ga} 2084.1$ constituting the back of the statue with part of the sampot, belt and associated pendants (fig. 9c). Fourth, the fragments ga 1170, ga 2988.7 and ga 2988.10 fit together (fig. 9d).

Additionally, ICP-AES analysis contributes to the completion of the "puzzle". The head (sample ga 5387-4), the back of the torso (sample ga 5387-7), the back fragment ga 2084.1 (sample ga 2084.1-1) and the ornament ga 741 (sample ga 741) are made of exactly the same metal (table 2a and fig. 5). Because of stylistic differences with the pendants at the back, ga 741 may have belonged to the front belt. This would imply that 

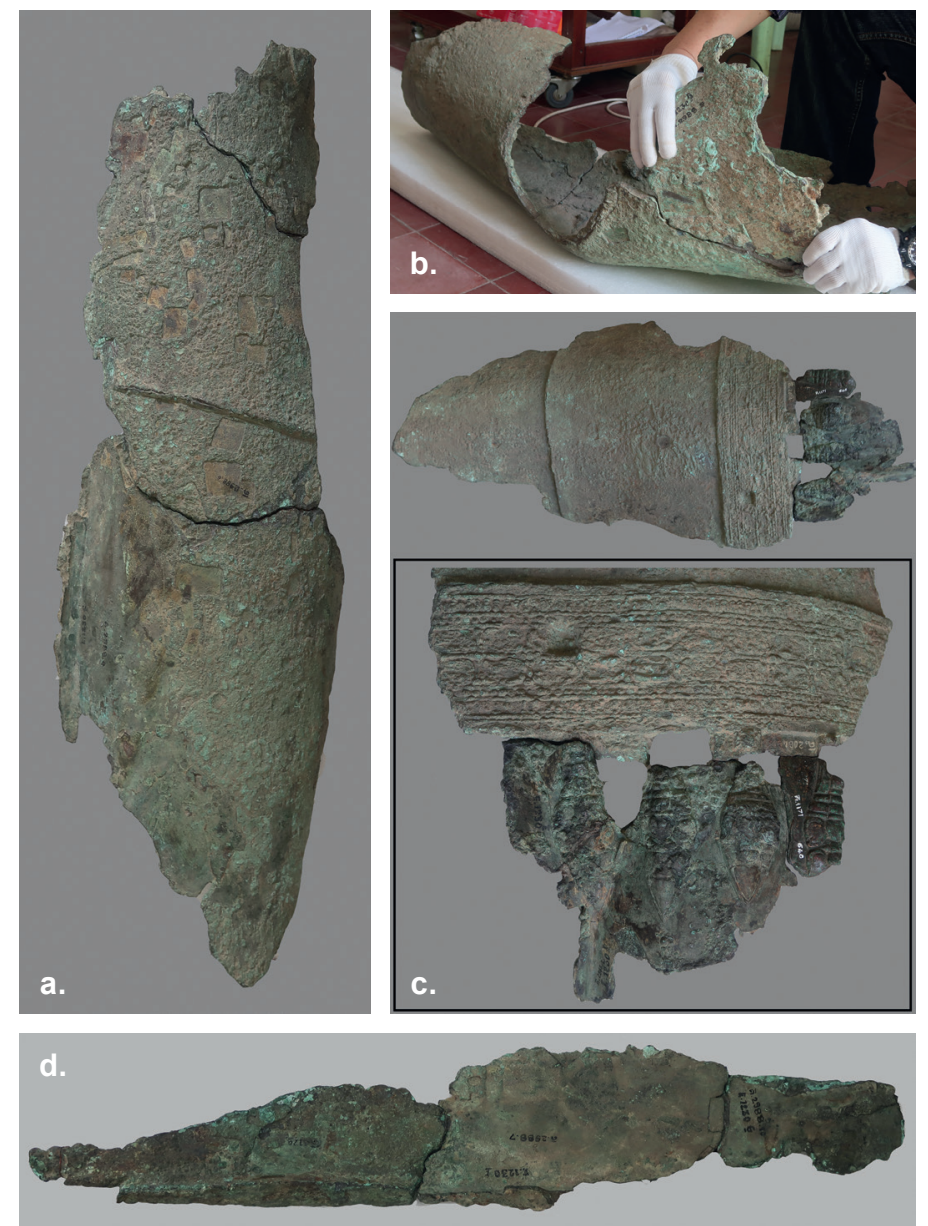

Fig. 9 - Reassembly of different fragments: (a) thigh with sampot (ga 2988.4, ga 2988.6 and ga 2988.8); (b) left arm ( $\mathrm{ga} 2084.2$ and $\mathrm{ga}$ 2988.9); (c) back with detail of the belt and pendants (ga 2084.1, ga 1171 and ga 2988.1); (d) fragments ga 1170, ga 2988.7 and ga 2988.10.

the whole torso - back and front - was cast in one go. A number of other fragments may be associated with this section as well. Some were already identified as part of the back, or to be close to it (samples ga 1173-2, ga 1188, ga 2988.1-1 and ga 2988.8-1). On the other hand, some fragments are still unidentified ( $g a$ 1174, ga 1175, ga 1210, ga 2988.5 [1\&2], ga 2988.11 and West Mebon 1).

Although identified by naked eye as belonging to the left arm fragment ga 2084.2, the fragment ga 2988.9 shows a metal composition that significantly differs from it (fig. 5). The composition of the left arm fragment ga 2084.2 (sample ga 2084.2-1) is closer to the one of the fragment ga 1166 (sample ga 1166). The hypothesis of the fragment $g a 2988.9$ being part of secondary casts may be raised. ${ }^{31}$ Similarly, the fragment with a belt pendant

31. Once the statue or parts of it were cast ("primary cast"), repairs or assemblies may be performed by adding some liquid metal ("secondary cast"). 
ga 1171, which is associated with the back fragment ga 2084.1, has a distinct composition. Another set of fragments clearly identified as secondary casts form a separate composition group as well (samples ga 5387-6 and ga 2988.1-2). Whether these secondary casts were part of the initial casting plan, or were repairs, is not clear at this stage. Finally, regarding the bust, the similar composition of the two right hands (samples ga 5387-1/2) and one of the left shoulder protuberances (sample ga 5387-5) provide another example of manipulation of large quantities of molten metal.

\subsection{Modeling}

\subsubsection{Wax model}

Wax-to-wax joins were observed on the bust, thus testifying for the use of a lost-wax technique with the wax model being designed in different parts (figs. 10a-b). This very probably holds for the whole statue. One wax-to-wax join is visible at the junction of the two right arms (figs. 11a-c), whereas those at the level of the right shoulder may be hidden behind the decorative armlets. Wax-to-wax joins were also noticed on the internal surface of fragments bearing ornaments ( $g a 1171$ and ga 2988.1; figs. 12a-b). Such depressions may suggest that the ornaments were separately modeled in molds and added to the primary wax model where holes were prepared (e.g., on the back). Additionally, a peculiar area showing an over-thickness is visible inside the head down to the neck, as if the face had been separately designed (fig. 13a).

Apart from the head and the thickening at specific locations, ${ }^{32}$ an astonishing homogeneity of the metal wall thickness was observed on the bust and on all fragments investigated, around 7 to $9 \mathrm{~mm}$. At this stage, it is not possible to state to which process(es) such homogeneity pertains to. Wax may have been directly modeled using wax sheets, as notably observed in modern Nepalese sculpture. ${ }^{33}$ Alternatively, wax may have been applied inside molds following what is called an "indirect process", either by pouring liquid wax ("slush molding") or by applying wax slabs in molds. Given the size of the statue and the differences of morphologies of the various parts (e.g., compare the hands and arms), it is probable that different processes were used contemporaneously.

The head exhibits several features that indicate the use of the "direct process", starting with the internal surface not conforming to the external design. The ears are also solid. Additionally, on the interior, the mouth is not visible and only a small depression marks the location of the nose (fig. 13b).

Finally, the discontinuity in the design of the right bracelets shows that they were independently shaped - directly or by using a mold - and rolled over the wrist (fig. 14).

32. Up to $15 \mathrm{~mm}$, mainly at edges where metal assembling was performed or where wax slabs overlap.

33. Craddock 2015: 72-76, figs. 24-25. 


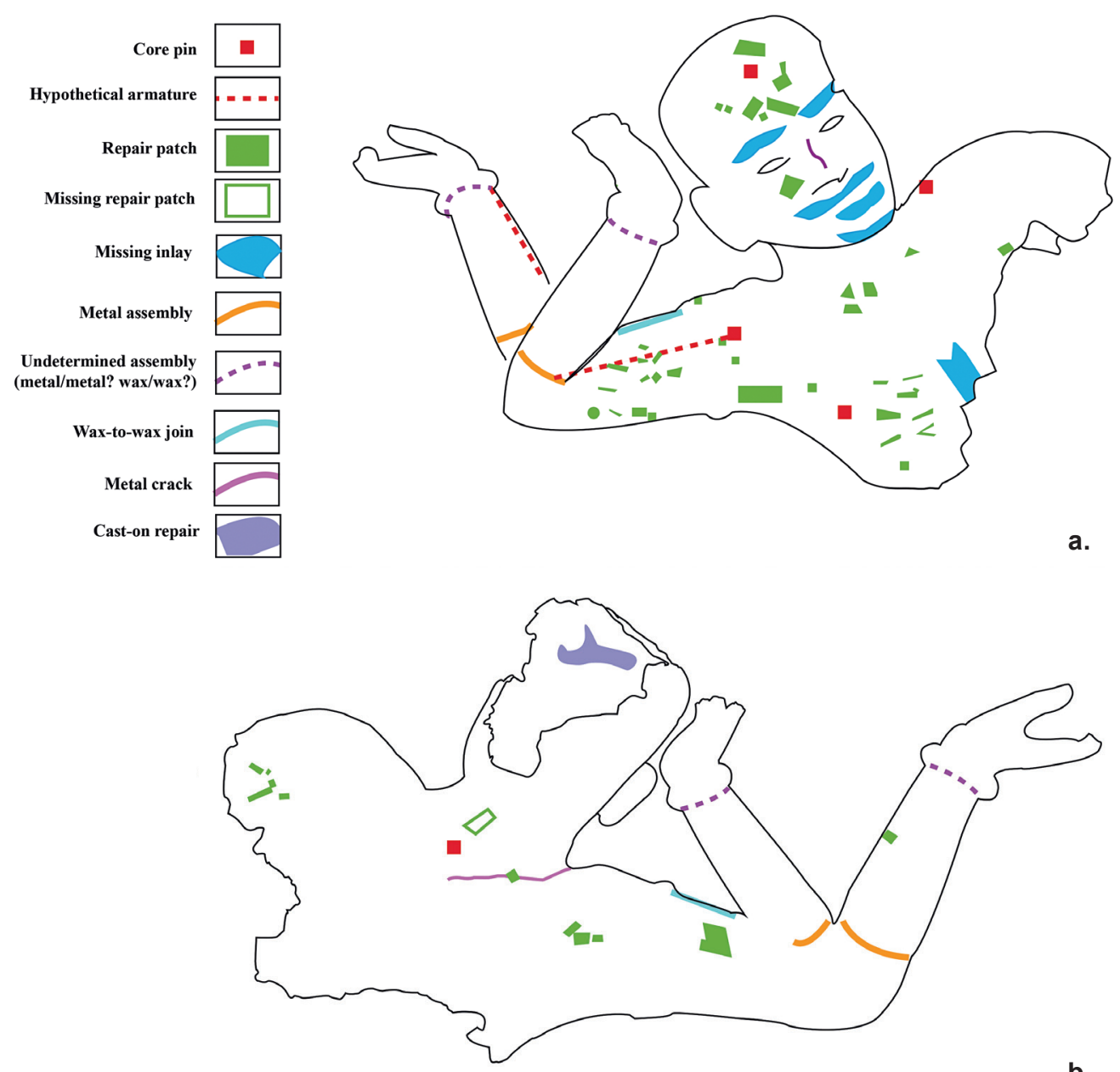

Fig. 10 - Technical scheme of the bust (ga 5387): (a) front view; (b) back view. Drawing: M. Castelle.
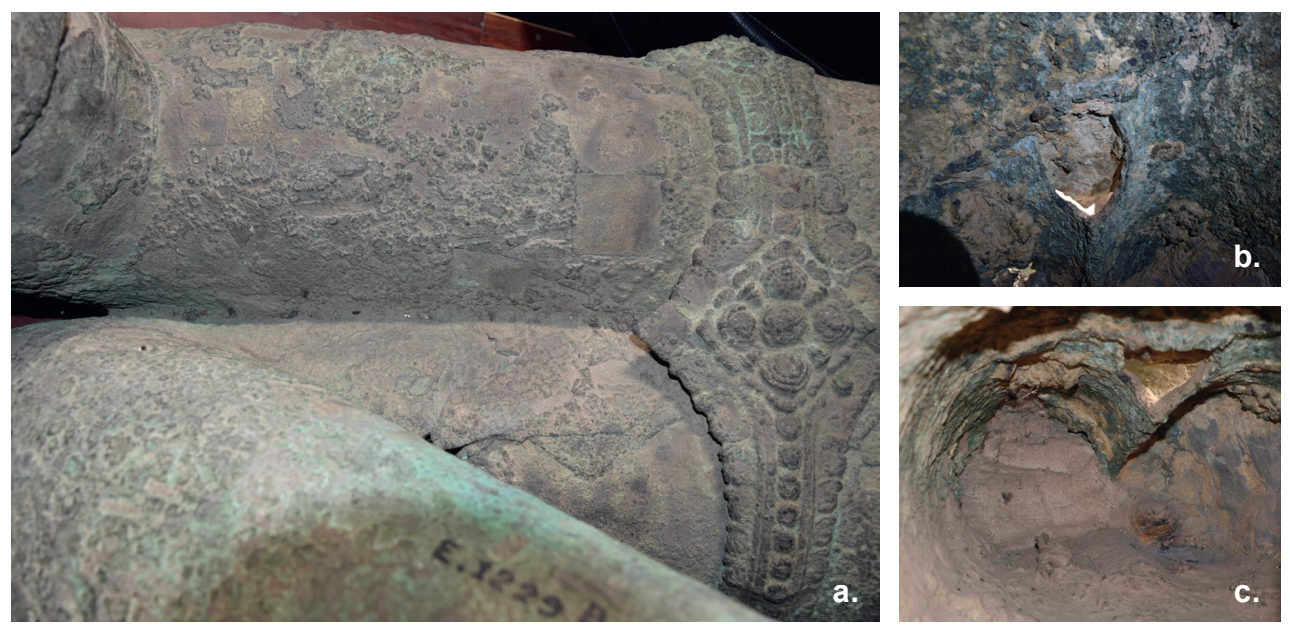

Fig. 11 - Wax-to-wax joins between the two right arms ( $\mathrm{ga}$ 5387): (a) view from above; (b-c) views from inside. 

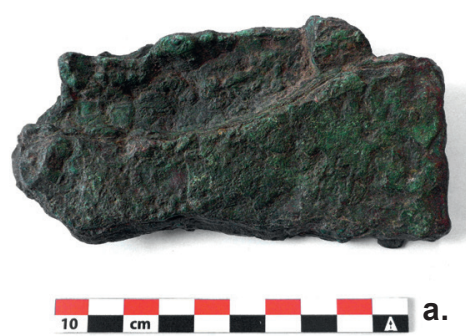

Fig. 12 - Fragments showing wax-towax joins on the internal surface between the ornamented and plain areas: (a) fragment ga 1171; (b) fragment ga 2988.1
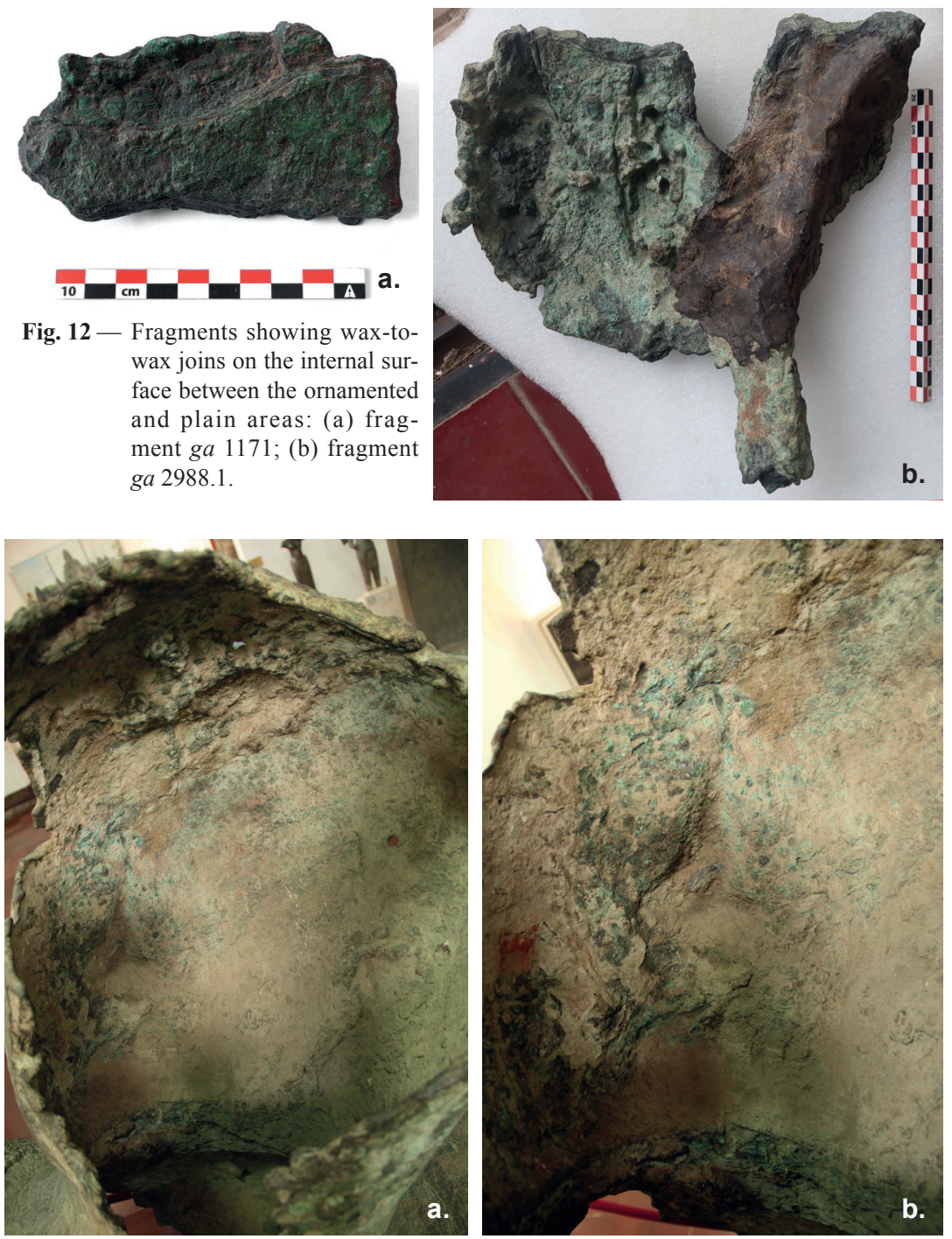

Fig. 13 - Views from the inside of the face ( $g a$ 5387) showing: (a) the over-thickness all around the face; (b) the rudimentary drawing of the mouth and nose (if any). Photos: S. Clouet.

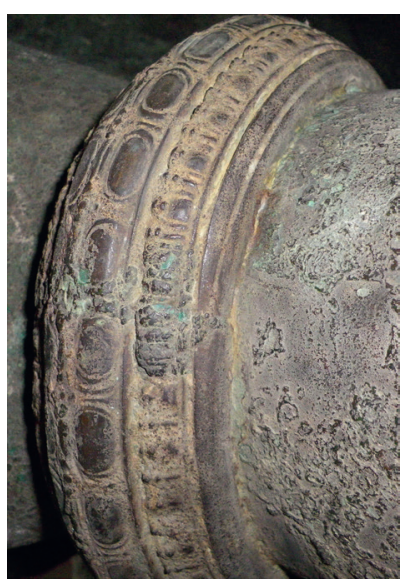

Fig. 14 - View of one of the right bracelets showing the design discontinuity due to the assembly of wax elements ( $g a$ 5387). 

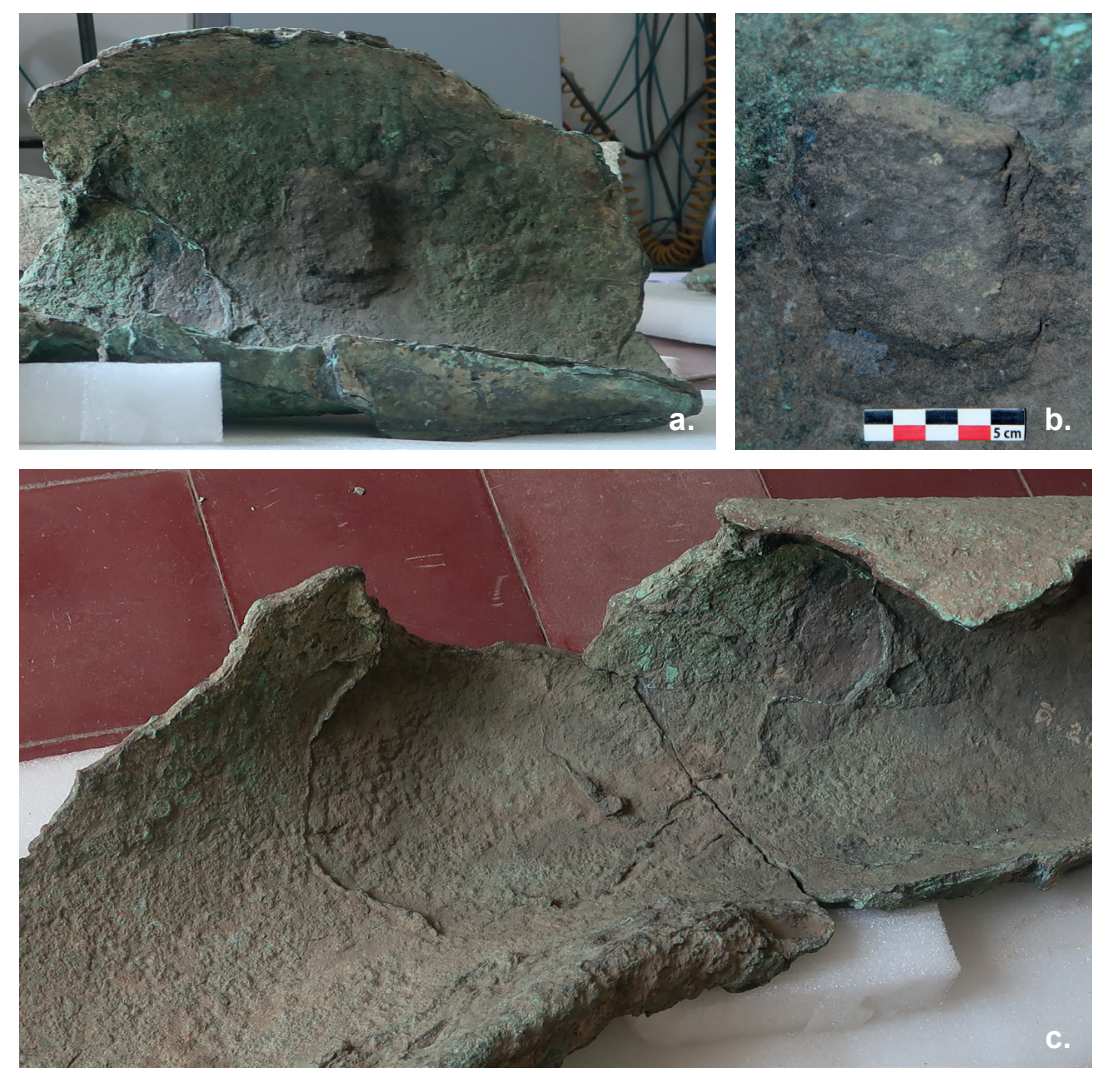

Fig. 15 - Views of the internal surface of the left arm fragment ga 2084.2 showing: (a-b) remains of clay core probably stemming from a secondary cast repair; (c) core flashes. Photo (15b): S. Clouet.

\subsubsection{Core and armatures}

The statue is hollow. Remains of grey to black material, visually identified as clay, were observed inside the right arms (fig. 11b), the nose, and the left arm fragment ga 2084.2 (figs. 15a-b). ${ }^{34}$ The clay had been heated and stuck to the metal wall. It clearly originated from the clay core and cannot be mistaken for soil from the burial environment. Core flashes are to be seen on the internal surface of several fragments (fig. 15c). Additionally, 10 and $20 \mathrm{~mm}$ square iron rod fragments were observed on both the external and internal surfaces of a number of fragments (bust ga 5387, ga 2084.2 and $g a$ 2988.9; figs. 16a-b). Some of them prove to be magnetic, suggesting the presence of core pins. ${ }^{35}$ Given the large size of some of the pieces, such as the torso, the clay core would have been reinforced with iron armatures, as seen in the right upper arm and in the fragment $g a 1170$. Yet there is no way

34. Because of its neat square shape, the core remains on the left arm fragment ga 2084.2 stems very probably from a cast-on repair; however, the external surface could not be observed in order to support this hypothesis.

35. Their role is to maintain the clay core within the investment mold during metal pouring, once the wax is melted out. 

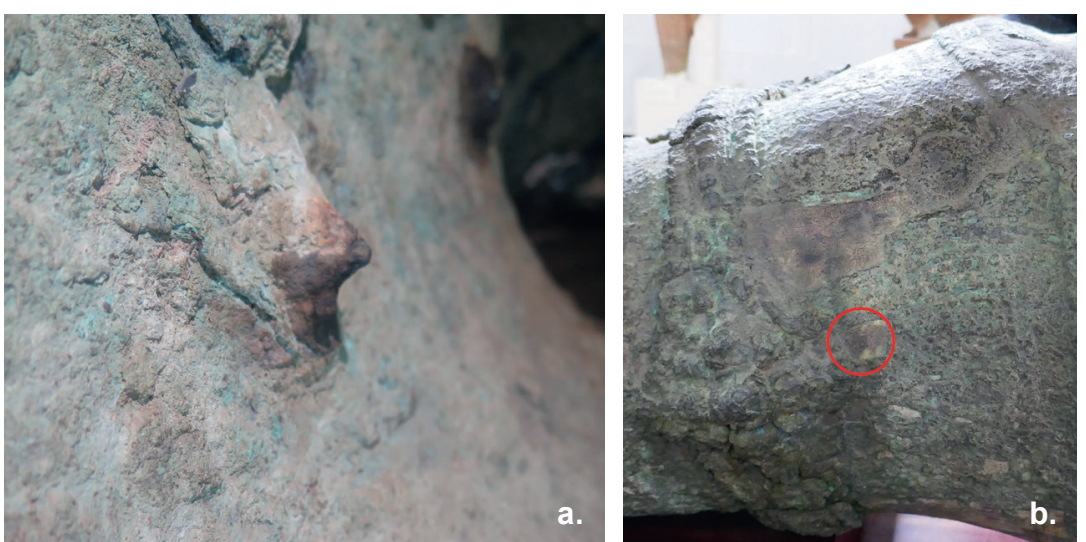

Fig. 16 - Examples of iron core pins: (a) left arm fragment ( $g a$ 2084.2); (b) right shoulder ( $g a$ 5387: red circle).
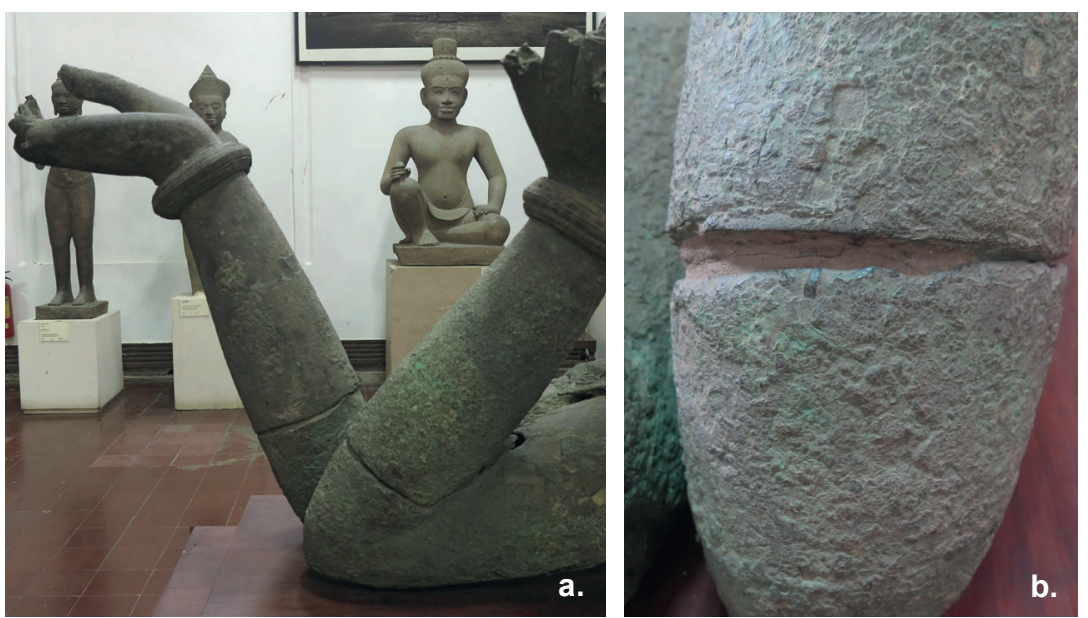

Fig. 17 - (a-b) Metal assemblies between the right arms and forearms ( $g a$ 5387).

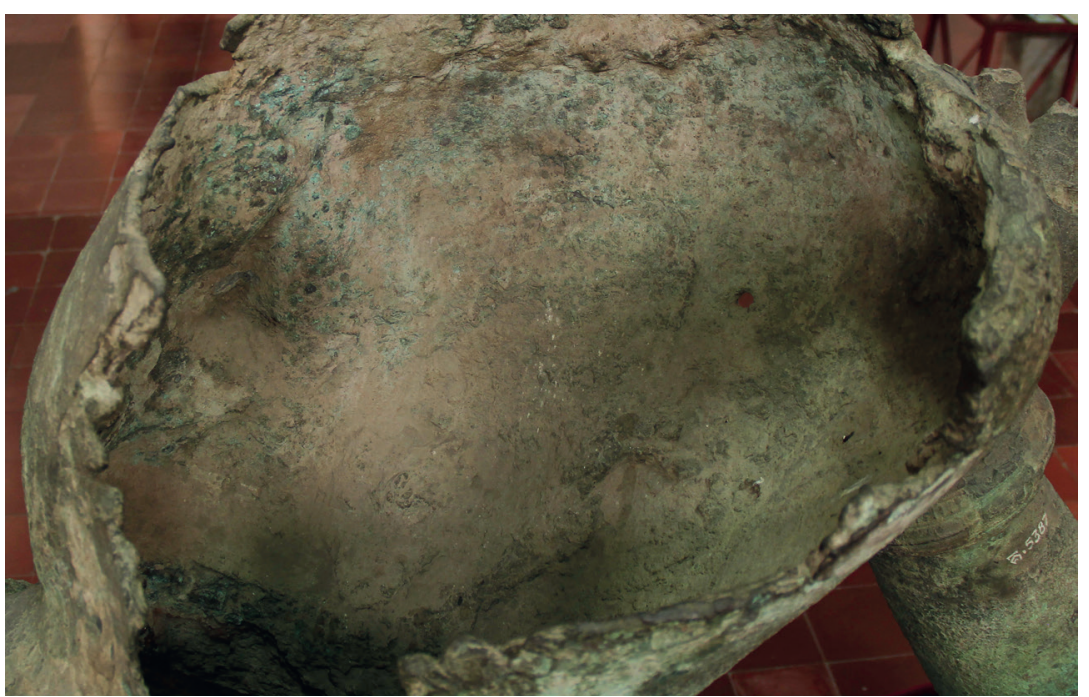

Fig. 18 - View of the back of the head showing the flat edges on both temples ( $g a$ 5387). Photo: S. Clouet. 

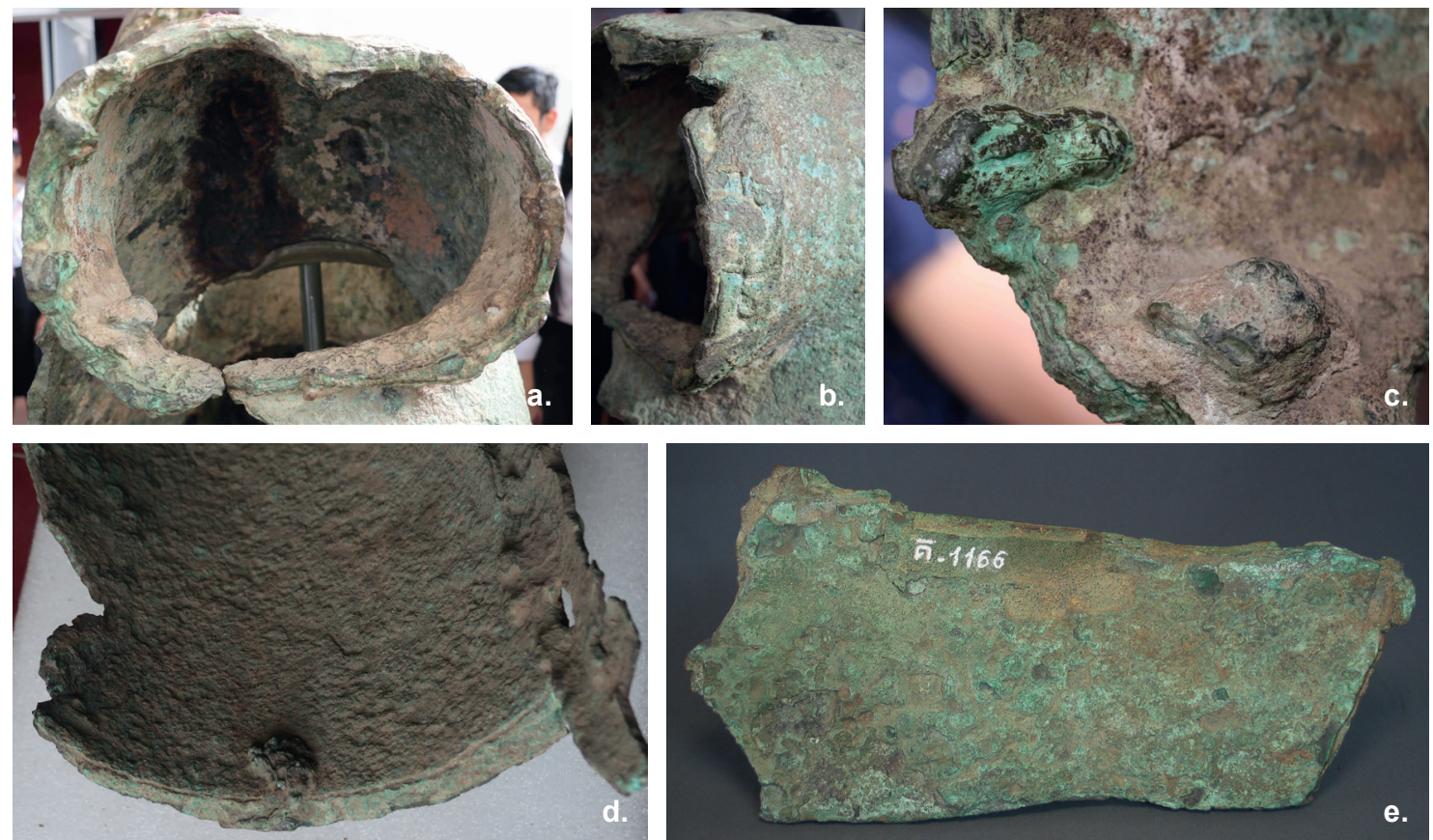

Fig. 19 - Assemblies by discontinuous metal sealing observed: (a-c) along the edge of the left shoulder ( $\mathrm{ga}$ 5387); (d) on the left arm fragment ( $g a$ 2084.2). (e) Interlock using recessed grooves (fragment $g a$ 1166).

to reconstruct the complete original armature system. It is very probable that most of the core, and thus the armatures, were withdrawn after casting, before assembling the different parts.

\subsection{A statue cast in several parts}

As already pointed out, the West Mebon Vișnu was cast in several parts. The bust itself is made of at least three separate sections (figs. 10a-b). The torso, down to the belt, and the right arms were cast altogether. The two right forearms were separately cast (figs. 17a-b). The two right hands are probably separate casts as well. One may wonder whether the upper back side of the head was separately cast. The flat and regular horizontal fracture surface at the level of the left and right temples may pertain to metal-to-metal joins (fig. 18). As mentioned above, the left arm was also joined to the bust. Similar evidences of metal joins were highlighted on the left shoulder and the left arm fragment ga 2084.2 (figs. 19a-d). Finally, the legs may have been separately cast and joined to the rest of the body. The excess of welding metal on both the main fragment of the back ( $g$ a 2084.1) and smaller fragments (e.g., ga 2988.4) testify to this.

Both metallurgical and mechanical joining were used. Six metal protuberances appear at regular intervals all along the edge of the left shoulder. The analysis of one of these revealed an alloy with slightly more lead than the primary cast ( $c a .3$ wt.\% lead, see sample ga 5387-6 in table 2a). These features were cast-on, probably in order to secure the edge-to-edge assembly 


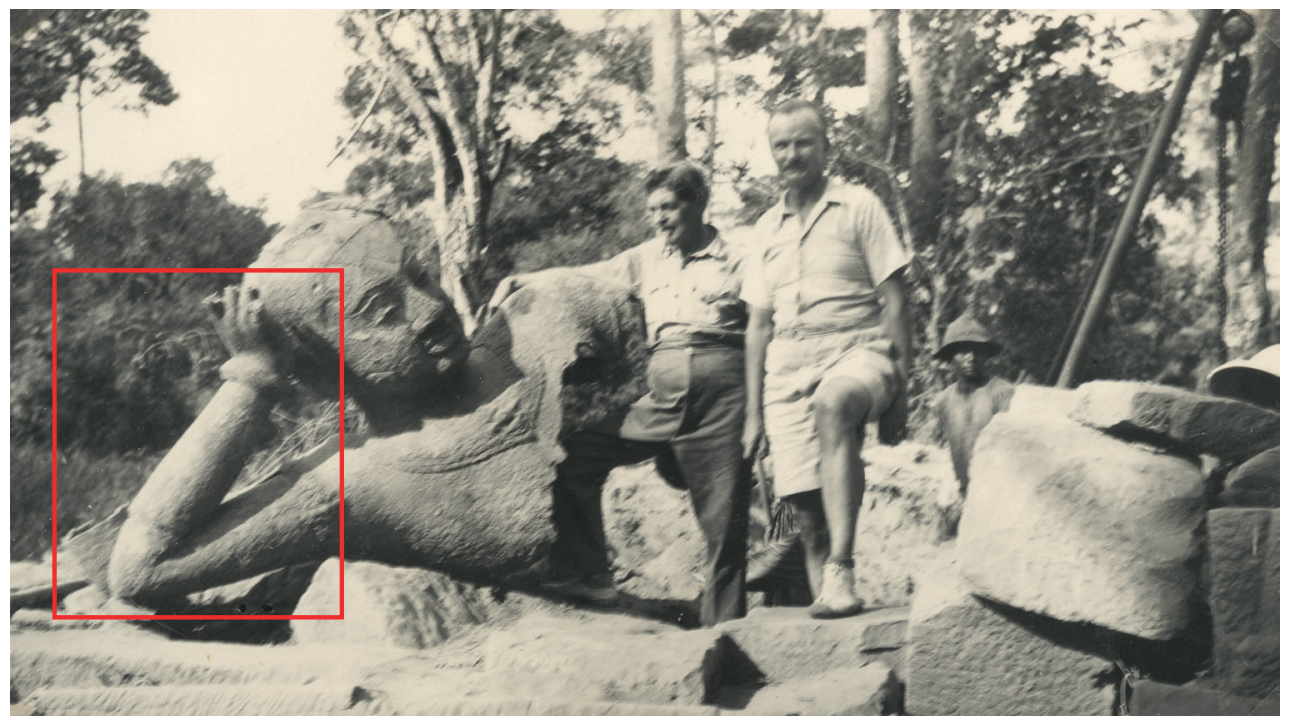

Fig. 20 - Bust of the West Mebon Vișṇu after excavation, without the upper right forearm. Photo: EFEO, fonds Henri Marchal, ref. MAR01728.

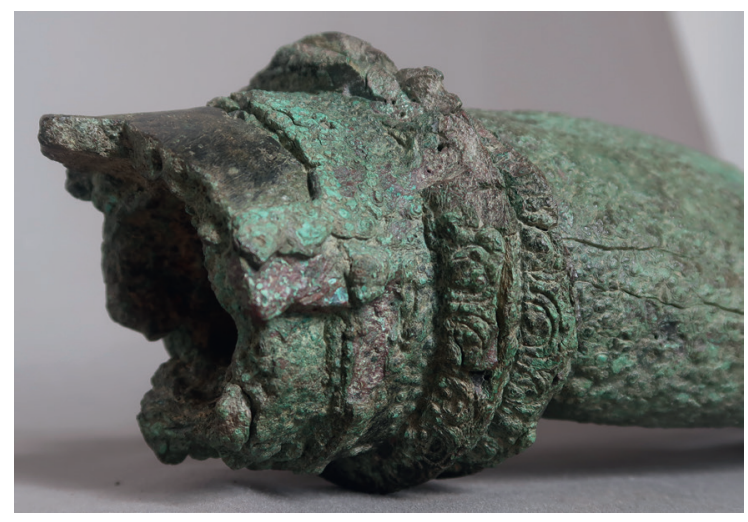

Fig. 21 - Detail of the left hand ga 5444 showing the still-attached forearm fragment and the assembly system based on four side grooves and secondary metal poured inside.

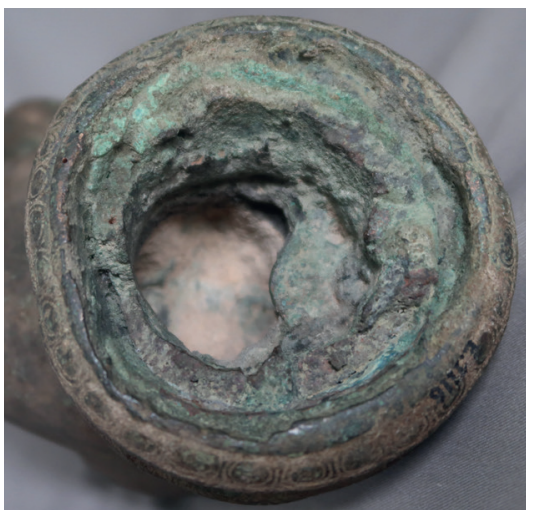

Fig. 22 - Detail of the right hand ga 5447 showing a possible fragment of the forearm still inside.

with the left arm. ${ }^{36}$ Recessed grooves were observed on the aforementioned areas, as well as on the fragment ga 1166 (fig. 19e). At this stage, it is not clear whether the grooves were shaped to mechanically secure the assembly or to be filled with secondary cast metal. The fragment ga 2988.1 corresponding to the upper junction of the legs with the back also shows a cast-on at the junction of the two legs (fig. 12b).

Similarly, edge-to-edge assembly was used to join the right arms and forearms, as evidenced by the flat edges of both parts clearly visible on archive pictures taken after excavation, and before their reassembly (figs. 2 and 20).

36. What appears to be a similar feature on the edge of the left arm fragment ga 2084.2 does not show any significant addition of lead. On the contrary, it is much lower in tin than the primary cast (10 versus 13 wt.\%, compare the samples ga 2084.2-1 and ga 2084.2-3 in table 2a). 


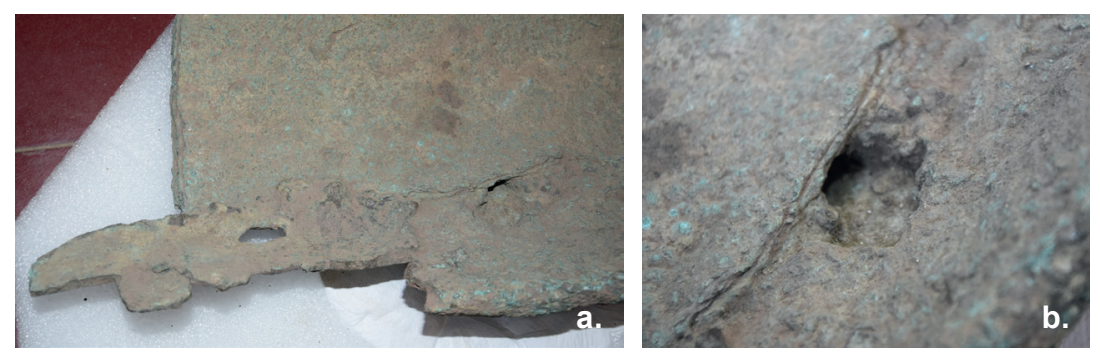

Fig. 23 - Assemblies by interlock: (a-b) holes on the cast-on band at the edge of the left arm fragment ( $g a$ 2084.2); (c) hook on the fragment ga 2988.9 associated with the upper part of $g a 2084.2$.

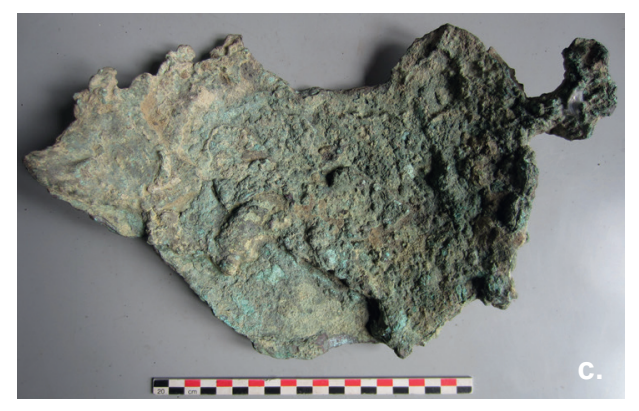

No feature related to mechanical joining or casting-on could be evidenced on the external surface of the junction. The interior area could not be observed due to later cement filling. It is likely that this assembly was secured by casting-on, as for the other parts of the statue. The left hand ga 5444 and the associated remains of forearm are assembled edge-to-edge as well, using a specific two-fold technique (fig. 21). A continuous cast-on seals both parts from inside. Additionally, four grooves are prepared on the external surface of both sections and filled with metal in order to secure the rotation. One of these grooves has probably been used as an entry point for the internal caston. In comparison, the right hand ga 5447 shows a sleeve join with cast-on metal inside to secure the assembly with the forearm (fig. 22).

Several holes were observed on the large band at the edge of the left arm fragment ga 2084.2 (figs. 23a-b).${ }^{37}$ They seem to be related to an interlock system: as for the one observed on the fragment $\mathrm{ga}$ 2988.9, pre-cast hooks were introduced into the holes to join the two parts (fig. 23c). ${ }^{38}$ It is not clear whether a second pour of metal was used to lock the system in place. Interestingly, the fact that these features are located on both opposite edges of the left arm fragment suggests that the arm was made of two separately cast shells.

Finally, some missing ornaments were probably mechanically attached to the body of the West Mebon Viṣnu. Five round holes are still visible around the forehead that could have served for the attachment of a diadem (fig. 24) ${ }^{39}$ Similarly, one round hole on the belt, plus possibly two larger

37. The composition of this so-called "cast-on band" is very similar to the composition of the main fragment. It is thus unlikely that this refers to a secondary cast.

38. This fragment originally comes from the upper part of the left arm fragment $g a$ 2084.2 (fig. 9b).

39. On this hypothesis, see also Boisselier 1956: 78; Feneley 2017: 202-203, 205. 


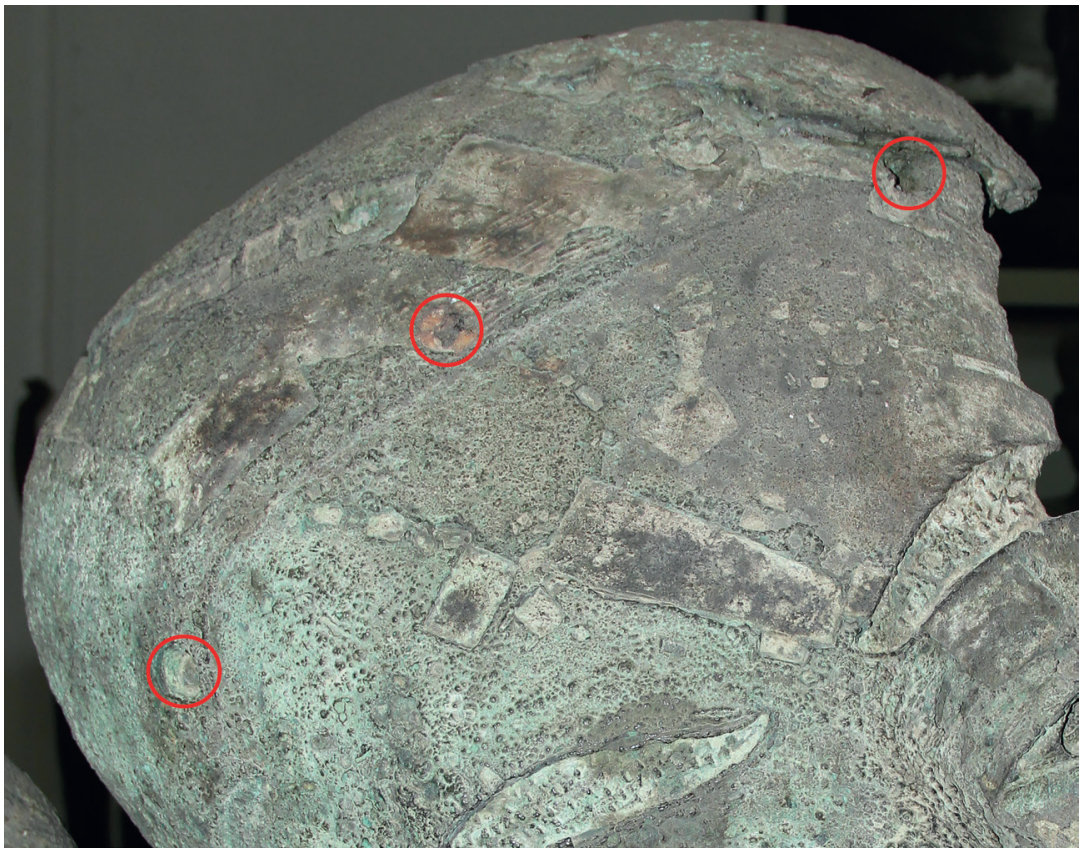

Fig. 24 - Forehead showing the holes for the attachment of a diadem ( $\mathrm{ga}$ 5387: red circles). Photo: S. Clouet.

rectangular holes - one is missing -, could testify for the fixing system of the decorative bow originally placed at the back of the sampot (fig. 9c). ${ }^{40}$ As for the earrings, the way used to attach them to the ears is not known, although soldering may be a possibility, as evidenced by at least another 11-century Khmer bronze statue. ${ }^{41}$

\subsection{Casting defects and repairs}

No evidence was brought to light to figure out how the different sections were cast. ${ }^{42}$ Numerous casting flaws were observed (figs. 25a-b): on the nose, behind the neck, or on the fragments ga 2988.4 and ga 2988.6. Porosity could be directly detected on the fracture surface of fragments $\mathrm{ga} 2084.1$ and $g a 2988.3$.

The flaws were repaired by two different processes, namely, by set-in and cast-on repairs. Preformed patches were hammered into the defects to fill the gaps. The edges of the defects were cut and cleaned in order to make the patch fit perfectly. On one location where the patch is missing (fragment ga 2988.9), a specific surface preparation could be evidenced with a regular

40. On this hypothesis, see also Feneley 2017: 207.

41. Vincent 2014a: 110-111, figs. 3.5.12a-b (cat. 3.5).

42. Neither traces of sprues nor localized porosity concentrations were observed that could help to reconstruct the gating system and notably what the orientation of the different sections was when the metal was poured (horizontal, vertical, upside down). 

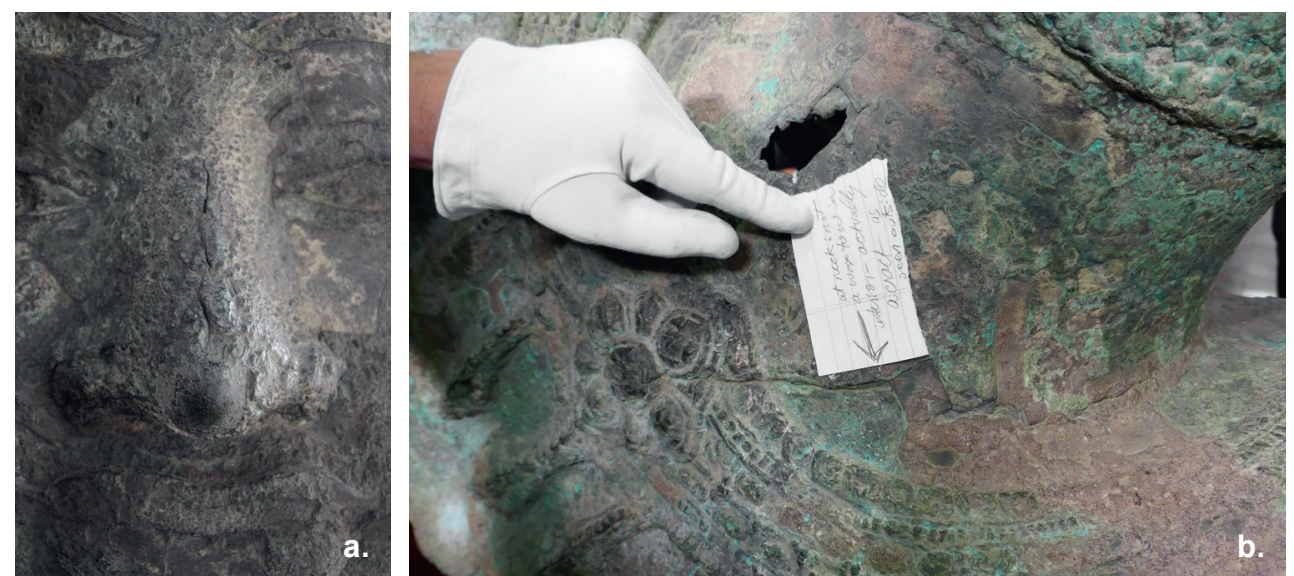

Fig. 25 - Examples of casting flaws (ga 5387): (a) detail of the nose; (b) back of the neck.
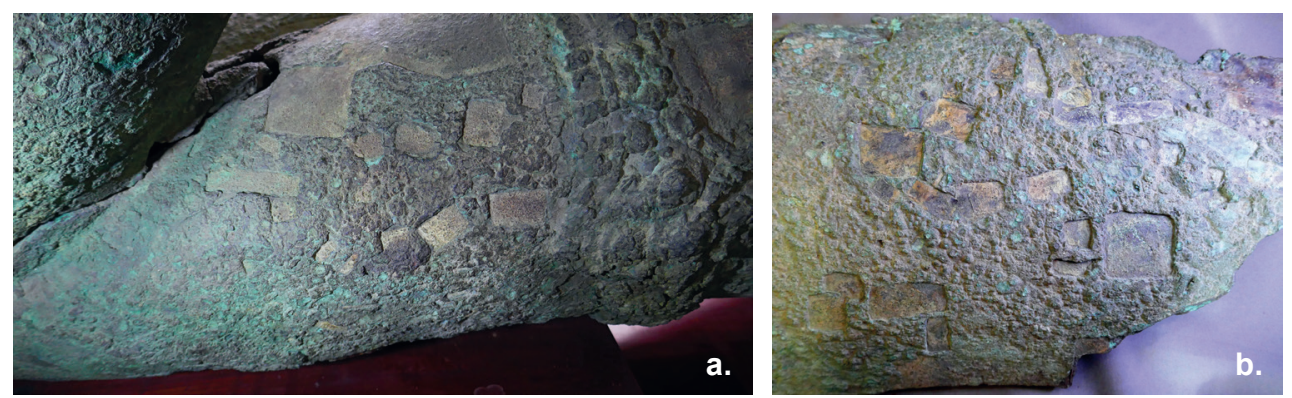

Fig. 26 - Examples of set-in patches used to repair the casting flaws: (a) on the lower right arm ( $g a$ 5387);

(b) on one of the right leg fragments ( $g a$ 2988.6).

$1 \mathrm{~mm}$ large groove all around. Such a preparation points to a mechanical attachment, similar to that observed for inlays. ${ }^{43}$ The form and size of the patches vary according to the defects. The size ranges from a few square millimeters to a few square centimeters. Shapes are mostly quadrangular, sometimes polygonal, whereas one round example was observed (figs. $26 a-b)$. When measured, the thickness of the patches varies between 1 and $3 \mathrm{~mm}$. The surface analysis by pXRFcarried out on seven patches on the bust and some fragments systematically revealed an unalloyed copper. ${ }^{44}$ The ICP-AES analysis of two patches (samples ga 1173-1 and ga 2988.8-2) points to quite similar impurity patterns than those of the bronze primary cast, if one excepts the much lower amounts of lead $(0.01$ versus $0.1 \mathrm{wt} . \%$; table 2a). Most patches proved to be magnetic, which is not surprising due to the relatively high iron contents measured on the two copper repairs analyzed. ${ }^{45}$ Note also that a peculiar iron-bearing corrosion was observed on the fragment $g a 1173$.

43. Untracht 1985: 304-319.

44. Again, the results are in agreement with the analysis made in the early 1950 s on a patch taken from the upper right forearm, which proved to be made of copper (Malleret 1954: 302-303). 45. $0.5 \mathrm{wt} . \%$ iron is enough for copper to be sensitive to a commercial magnet. However, part of the high iron and cobalt contents in sample ga 1173-1 is due to contamination during sampling. 

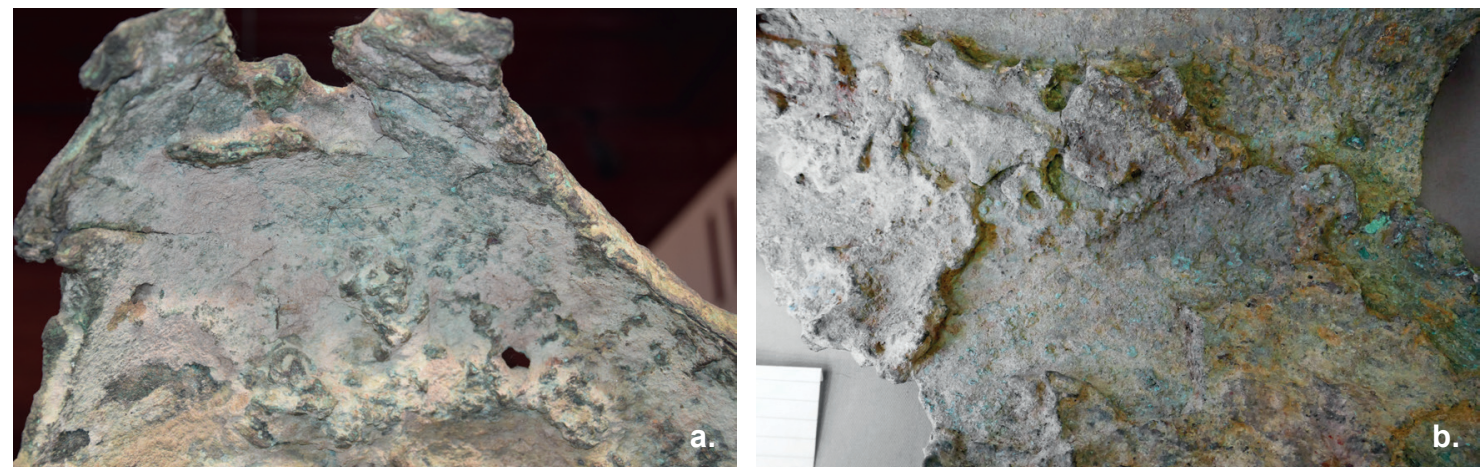

Fig. 27 - Examples of cast-on repairs: (a) inside the front upper part of the head ( $\mathrm{ga} \mathrm{5387)}$; (b) inside one of the right leg fragments ( $g a$ 2988.4).
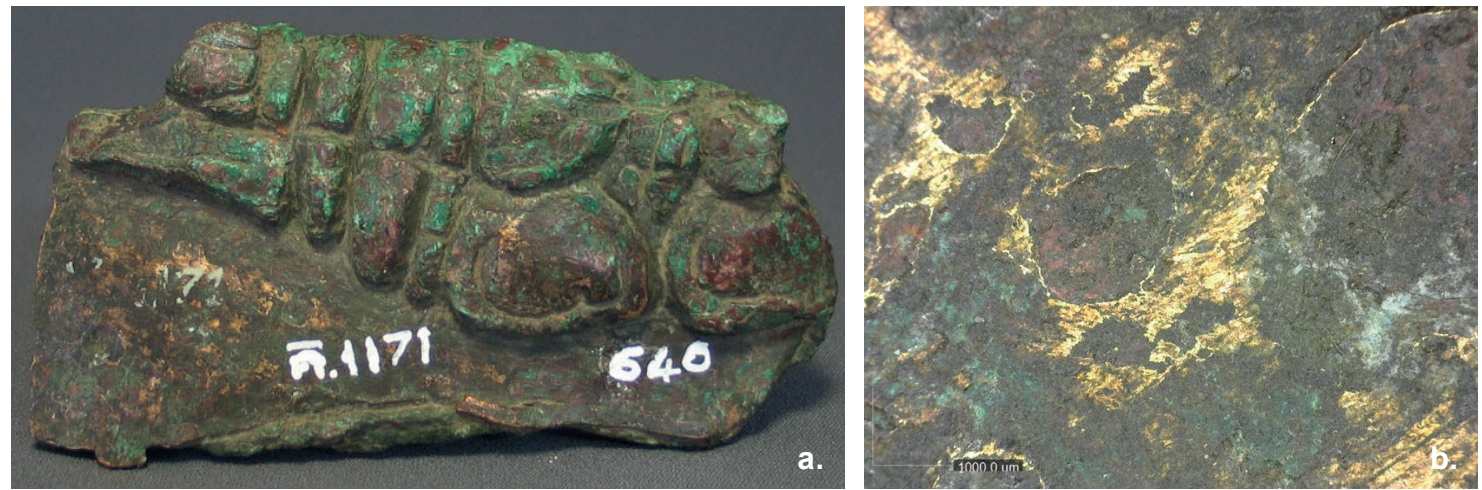

Fig. 28 - Remains of gilding on the fragment ga 1171: (a) general view of the external surface; (b) detailed view using microscopy.

Complex and/or large defects were filled by cast-on metal (figs. 27a-b). The metal of one cast-on repair was analyzed (sample ga 2988.1-2) showing a slightly different alloy from the primary cast, with less tin (8 wt.\%) and much more lead (4 wt.\%). It also shows higher amounts of arsenic (0.4 wt.\%), silver (0.1 wt.\%), bismuth (500 ppm), and gold (100 ppm).

\subsection{Finishing}

Because of the heavily altered surface, it is difficult to infer whether the incised decorations (e.g., all the lines underscoring the neck, eyes, lips) were worked on the wax model or later on the cast, or on both, and how this was done (chasing, engraving). One would hardly imagine such a piece of art not having been cold worked after casting.

A number of evidences show that the statue was entirely gilded. Numerous remains of gilding were observed by naked eye and using microscopy on the bust and several fragments (ga 1141, ga 1171, ga 1173, ga 1230 and ga 2988.4; figs. 28a-b). These observations were confirmed by pXRF analysis: gold was detected on more than 15 locations including the flesh (back, shoulder, neck, below the lower lip, right arms) and 

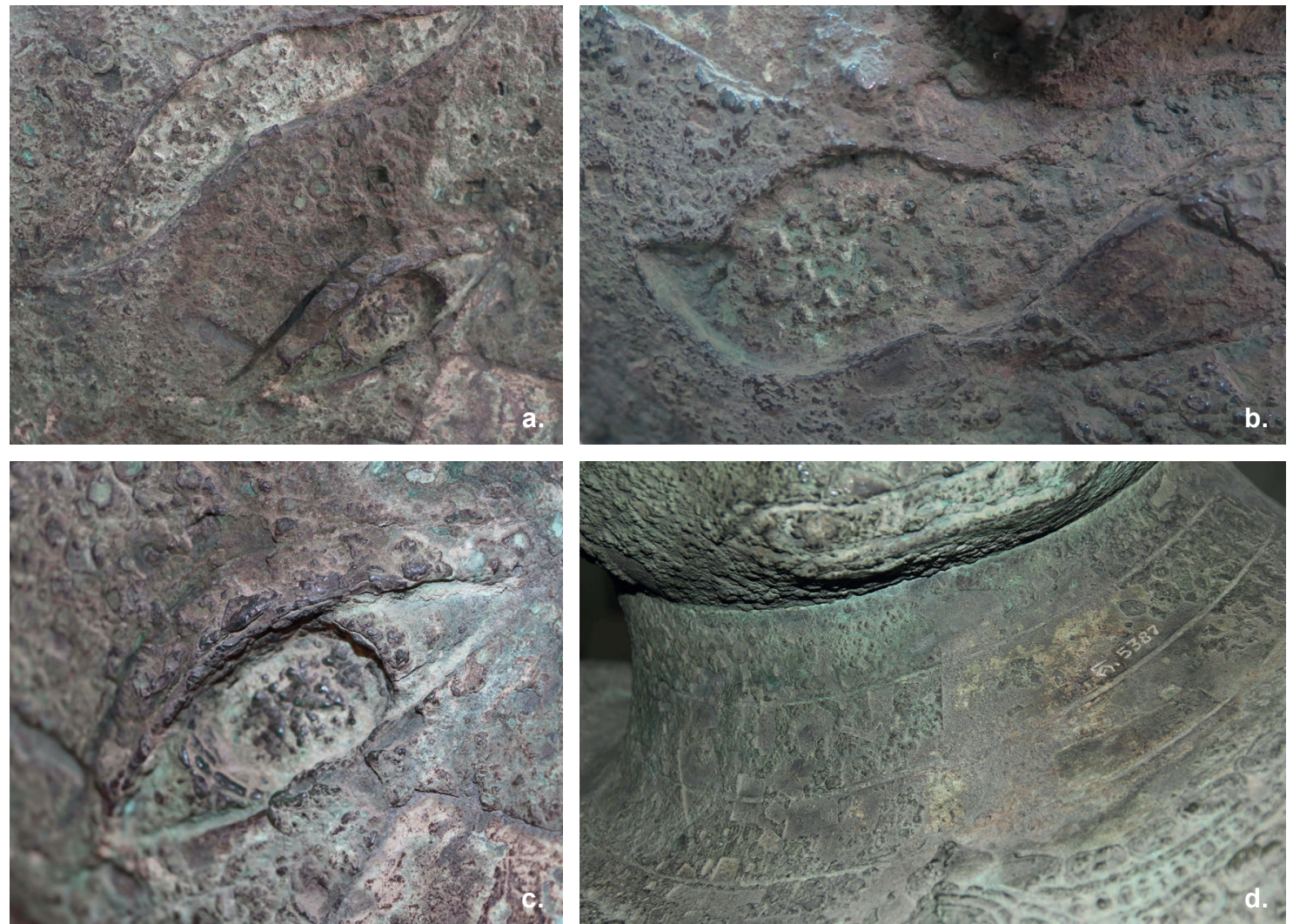

Fig. 29 - Inlaying ( $g a$ 5387): (a-b) detail of the right eyebrow and moustache showing the surface preparation for inlays; (c) detail of the right eye inlay; (d) detail of the neck decoration. Photo (29d): S. Clouet.

decoration (necklace). Total gilding of the surface would have served to conceal the many coppery-colored repair patches on the yellow tin-bronze alloy. Mercury was also sporadically detected, which may testify to fire or amalgam gilding.

Inlays creating polychromatic effects also belonged to the decorative repertoire. The lips were inlaid using copper, as shown by minute remnants and $\mathrm{pXRF}$ analysis. A particular surface preparation for inlays is visible at the eyebrows, moustache and chin beard (figs. 29a-b). There, the whitish material still entrapped in the recesses proves to be rich in lead, thus pointing to a lead-base compound. A good candidate would be lead carbonate, which is a soft paste easy to work and to color with pigments, as suggested by evidences found on a few other 11th-century Khmer bronze statues. ${ }^{46}$ The pupils of the eyes have a $1 \mathrm{~cm}$ deep recess for inlay but no evidence was found for the inlay material (glass or stone), nor for the means of fixing the inlay (fig. 29c). Similarly, the four grooves on the neck (beauty marks) were very probably inlaid, with silver or tin, although this was not confirmed neither by observation nor by analysis (fig. 29d).

46. Vincent 2014a: 53-54, fig. 3.1.13 (cat. 3.1); 113, fig. 3.5.21 (cat. 3.5). 


\subsection{Original display}

Since most of the lower part of the West Mebon Viṣnu has disappeared - around $60 \%$ of the entire statue is missing according to M. Feneley ${ }^{47}-$, the exact display of the statue in its shrine is difficult to assess. However, a few remarks can be made based on January 2018 observations. First, the back fragment ga 2084.1 shows two large metal protuberances at the bottom, on the internal surface, that bear exactly the same metal composition than the surrounding primary cast (fig. 3). These cannot be sprues, yet their precise function remains unclear. One may wonder whether these were part of the mounting system. Additionally, what was visually suggested to be calcite deposits seem to be more significant on the bust, under the arms, thus possibly testifying to a former path for running water. ${ }^{48}$

\section{Conclusion and future work}

\subsection{A number of new results}

The technical investigation of the West Mebon Viṣnu during a very shorttime period (one day and a half) by twenty scholars stemming from diverse countries, fields and disciplines proved to be very informative, at two levels.

On the one hand, as expected, numerous issues regarding technical vocabulary and interpretations were raised, confirming the need for a Guidelines for the Technical Examination of Bronze Sculpture. This is the objective of the ongoing CAST:ING project. The present paper aims at gathering all opinions and adopting the most consensual vocabulary when possible.

Secondly, a number of fundamental technical observations and constructive discussions were raised, leading for the first time to the understanding of the main fabrication techniques. The West Mebon Vișṇu was modeled in wax in several pieces using different processes including direct and indirect lost-wax casting. Although cast in several parts, the statue demonstrates the mastery of very large castings, as exemplified by the whole torso having been cast in one go. The joining techniques seem to be mainly based on edge-to-edge assembly secured by secondary casting, although mechanical joining was brought to light as well. The West Mebon Vișṇu also proved to be entirely gilded, with an exquisite polychromy of the face provided by a variety of inlays. The alloy composition matches well with what is known so far of 11th-century Khmer bronze statuary and may thus point to a centralized production area. In addition to technical clues, several major fragments were reassembled based on observations, measurements and metal composition. The identification of a large fragment of the left arm is one such achievement.

47. Feneley 2017: 201.

48. As mentioned above, two copper fragments of tube or collar, now missing, were discovered in the "eastern shaft" of the West Mebon temple in 1944. More recently, a new fragment of tube, this time made of bronze, was unearthed in June 2016 at the north of the central platform (pers. comm. M. Beaufeist, June 2018). On the long debate on the West Mebon Viṣnu considered or not as a water fontain, based on Zhou Daguan's testimony, see for example Dumarçay \& Royère 2001: 23 n. 14. 


\subsection{A number of new questions}

Meanwhile, new questions about the fabrication process arose that are crucial for the full comprehension of the West Mebon Viṣnu and, particularly, the context of production. First, the comparison with non-monumental casts may notably prove to be very informative for the characterization of the workshop involved. The following research avenues would also deserve particular attention. The lost-wax technique(s) used need to be precisely characterized for efficient comparison with what is known for smaller statuary. The quality of the cast and the repairing techniques are another discriminative feature to better understand the context of production (quantification of defects and porosity, quantification of patches). A detailed map of the assemblies is needed as well, together with the characterization of the corresponding techniques. Gilding, especially fire gilding, deserves similar attention, as well as inlaying techniques, with priority for the determination of the lead-base compound and comparison with stone statuary. The results regarding metal composition also need some more work for more accurate provenancing, together with the ongoing LANGAU research project. The original display of the West Mebon Viṣnu is a crucial point as well. Further investigation may help to understand the mounting and thus the original pose of the statue. Given the importance of water with respect to its display and function, a proper characterization of the calcite deposits on the bust would be of much interest. Finally, recent excavations and cleanings at the West Mebon temple have brought to light a number of large sandstone blocks and slabs - in addition to those already found by M. Glaize in 1944 - , which would deserve further study.

To address all these issues, more observations are needed, by naked eye and digital microscopy together with focused technical photography. Further technical investigations are also required. The X-ray radiography of the head and torso would be essential to the understanding of the chaine opératoire. The notable thickness of recesses in the head and of ornaments (more than $2 \mathrm{~cm}$ ) would require non-conventional radiography techniques such as gamma radiography. Complementary analysis of gilding using more sensitive techniques is needed to check whether fire gilding was systematically used or not. Infrared and Raman spectrometry together with chromatography would also help characterizing the lead-base compound. Petrographic analysis of the clay core would be very helpful for provenancing, with comparison with the clay deposits in and around Angkor. ${ }^{49}$ Iron armature analysis and dating, in relation with the ongoing IRANGKOR research project, should be privileged as well, yet the high degree of corrosion of the few iron remnants would make it quite difficult. Finally, 3D scan and photogrammetry are highly recommended to help investigating the reassembled fragments and the original pose of the statue.

49. Only the clay core of the right hand ga 5447 was analyzed thus far; see Reedy \& Meyers 2007 (PM20); Vincent 2014b: 27-29 (cat. 3.5). 


\subsection{Conservation}

Thanks to the expertise of the MCL, the West Mebon Vișnu is in a stable condition. In December 2017, the bust has undergone a cleaning treatment, mostly to get rid of the dust. This proved to be of great help for the January 2018 technical study. Although no active corrosion could be evidenced, the bust and fragments are heavily corroded due notably to their long burial, in a very wet environment, at the West Mebon temple. This would deserve a few comments in the light of the present paper and for future decisions. It would be worth discussing whether the visibility of all the decoration including gilding, inlays and cold work (chasing marks) may be enhanced, and how. At the very least, since the gilding and inlay remains are rare, they deserve particular care..$^{50}$ The rationale for a homogenization of the surface appearance may be approached as well, particularly between the primary cast showing a very rough surface and the numerous smooth copper repair patches (fig. 26). ${ }^{51}$

Finally, in the eventuality of a metal copy of the bust of the Viṣnu being made for display at the West Mebon temple, the technical results obtained through further investigations could help guiding the reproduction in a modern casting process. The crucial issue of the original display of the statue would be tackled as well.

\section{Abbreviations}

AS

acc. no.

BEFEO

$\mathrm{C} 2 \mathrm{RMF}$

CMA

EFEO

$\mathrm{H}$.

ICP-AES

$J F C A$

L.

MCL

MMA

MNAAG

nd

NMC

PCA
Asia Society, New York accession number Bulletin de l'École française d'Extrême-Orient Centre de recherche et de restauration des musées de France, Paris Cleveland Museum of Art École française d'Extrême-Orient height Inductively coupled plasma atomic emission spectrometry Journal de fouilles de la Conservation d'Angkor (Archives de l'EFEO)

$$
\text { length }
$$

Metal Conservation Laboratory, Phnom Penh

Metropolitan Museum of Art, New York

Musée national des arts asiatiques - Guimet, Paris

not detected

National Museum of Cambodia, Phnom Penh

Principal components analysis

50. On archaeological items, corrosion frequently develops between the metallic substrate and the gilded layer, thus leading to its lifting (Robcis et al. 2017). Such risk should be checked on the West Mebon Vișṇu.

51. The reason for such differentiated corrosion is not clear yet (differences of composition or microstructure). The phenomenon would deserve more studies. 
PEFEO Publications de l'École française d'Extrême-Orient

PIXE Proton-induced X-ray emission

ppm parts per million

pXRF Portable X-ray fluorescence

RCA Rapport de la Conservation d'Angkor

TAASA The Asian Arts Society of Australia

th. thickness

Undet. undetermined

W. width

wt.\% weight percent

\section{Bibliography}

BoISSELIER, Jean

1955 La statuaire khmère et son évolution, Saigon, EFEO (PEFEO 37), 2 vols.

1956 Tendances de l'art khmèr. Commentaires sur 24 chefs-d'œuvre du Musée de Phnom-Penh, Paris, Presses universitaires de France (Publications du Musée Guimet, Bibliothèque de diffusion 62).

1966 Manuel d'archéologie d'Extrême-Orient, Première Partie. Asie du Sud-Est, Tome I. Le Cambodge, Paris, éditions Picard.

1967 "Notes sur l'art du bronze dans l'ancien Cambodge", Artibus Asiae 29 (4), pp. 275-334.

Bourgarit, David \& Benoît Mille

2003 "The elemental analysis of ancient copper-based artefacts by Inductively-Coupled-Plasma Atomic-Emission-Spectrometry (ICP-AES): an optimized methodology reveals some secrets of the Vix Crater", Measurement Science and Technology 14, pp. $1538-1555$.

Bourgarit, David, Benoît Mille, Thierry Borel, Pierre Baptiste

\& Thierry ZÉPHIR

2003 "A millenium of Khmer bronze metallurgy: analytical studies of bronze artifacts from the Musée Guimet and the Phnom Penh National Museum", in P. Jett, J.G. Douglas, B. McCarthy \& J. Winter (eds.), Scientific research in the field of Asian art: Proceedings of the First Forbes Symposium at the Freer Gallery of Art, London, Archetype Publications, pp. 103-126.

Brand, Michael \& Phoeurn Chuch

1992 The Age of Angkor: treasures from the National Museum of Cambodia, Canberra, Australian National Gallery (Studies in Asian Art 1).

Bunker, Emma C. \& Douglas LATCHFORD

2008 Khmer gold: gifts for the gods, Chicago, Art Media Resources.

2011 Khmer bronzes: new interpretations of the past, Chicago, Art Media Resources. 
CRaddock, Paul T.

2015 "The metal casting traditions of South Asia: continuity and innovation", Indian Journal of History of Science 50 (1), pp. 55-82.

DALSHEIMER, Nadine

2001 Les collections du musée national de Phnom Penh. L'art du Cambodge ancien, Paris, EFEO \& Magellan.

DumarÇAY, Jacques

1982 "Notes d'architecture javanaise et khmère", BEFEO 71, pp. 87-146.

DumarÇAy, Jacques \& Pascal RoyÈre

2001 Cambodian architecture: eighth to thirteenth centuries, Leiden, E.J. Brill (Handbook of Oriental Studies, Section Three. SouthEast Asia 12).

Feneley, Marnie

2006 "The West Mebon Vishnu", TAASA Review 15 (3), pp. 18-19.

2013 "The context of the West Mebon Viṣnu", in M.J. KLoKke \& V. Degroot (eds.), Materializing Southeast Asia's past: selected papers from the 12th International Conference of the European Association of Southeast Asian Archaeologists, Singapore, NUS Press, vol. 2, pp. 140-155.

2014 "The West Mebon Visnu: style, hydraulics and political power", Unpublished Ph.D. Thesis, Sydney, University of Sydney.

2017 "Reconstructing god: proposing a new date for the West Mebon Vișnu, using digital reconstruction and artefactual analysis", Australian and New Zealand Journal of Art 17 (2), pp. 195-220.

Feneley, Marnie, Tom Chandler, Nils Gleissenberger \& Ben Alexander

2008 "Reconstructing the West Mebon Vishnu: a marriage of traditional artefactual analysis with digital 3D visualization", in T.G. Wyeld, S. Kenderdine \& M. Docherty (eds.), Virtual systems and multimedia: 13th International Conference, VSMM 2007, Brisbane, Australia, September 2007, Revised selected papers, Berlin-New York, Springer, pp. 73-87.

Feneley, Marnie, Dan Penny \& Roland Fletcher

2016 "Claiming the hydraulic network of Angkor with Visnu: a multidisciplinary approach including the analysis of archaeological remains, digital modeling and radiocarbon dating: with evidence for a 12th century renovation of the West Mebon", Journal of Archaeological Science: Reports 9, pp. 275-292.

GerschHeImer, Gerdi \& Brice Vincent

2010 "L'épée inscrite de Boston (K. 1048, 1040-41 de notre ère)", Arts Asiatiques 65, pp. 109-120.

GiteAu, Madeleine

1965 Les Khmers. Sculptures khmères. Reflets de la civilisation d'Angkor, Fribourg, Office du Livre.

Glaize, Maurice

1963 Les monuments du groupe d'Angkor, Paris, Adrien Maisonneuve [1st ed. 1948]. 
Grosuler, Bernard Philippe

1961 Indochine. Carrefour des arts, Paris, Albin Michel.

GuY, John

2010a "Angkorian metalwork in the temple setting: icons, architectural adornment, and ritual paraphernalia", in L.A. CORT \& P. JETT (eds.), Gods of Angkor: bronzes from the National Museum of Cambodia, Washington, D.C., University of Washington Press, pp. 88-129.

2010b "Vishnu reclining on the serpent Anantha", in C. Bell (ed.), What makes a masterpiece: artists, writers and curators on the world's greatest works of art, London, Thames \& Hudson, pp. 72-75.

HARRIS, Peter

2007 A record of Cambodia: the lands and its people, Chiang Mai, Silkworm Books.

Jessup, Helen I.

2006 Masterpieces of the National Museum of Cambodia, Phnom Penh, FOKCI.

JESSUP, Helen I. \& Thierry ZéPHIR (eds.)

1997 Angkor et dix siècles d'art khmer, Paris, Réunion des musées nationaux.

KHUN, Samen

2013 The new guide to the National Museum, Phnom Penh, Phnom Penh, Ariyathoar [4th ed].

Loвo, Wibke (ed.)

2006 Angkor. Göttliches Erbe Kambodschas, Bonn, Kunst- und Ausstellungshalle der Bundesrepublik Deutschland GmbH/ München, Prestel.

MALLERET, Louis

1954 "À propos d'analyses de bronzes archéologiques", Bulletin de la Société des Études Indochinoises 29 (4), pp. 297-307.

Marchal, Henri

1936 "Chronique de l'année 1936. Cambodge. Mébon occidental", BEFEO 36 (2), p. 611, pl. XCIII.

Oun, Phalline \& Martin Polkinghorne

2010 "In the public domain: a new display at the National Museum of Cambodia", TAASA Review 19 (2), p. 17.

Pelliot, Paul

1951 Mémoires sur les coutumes du Cambodge de Tcheou Ta-kouan, Paris, Adrien Maisonneuve (Euvres posthumes de Paul Pelliot 3).

Penny, Dan, Christophe Pottier, Matti Kummu, Roland Fletcher,

Ugo Zoppi, Mike Barbetti \& Somaneath Tous

2005 "Hydrological history of the West Baray, Angkor, revealed through palynological analysis of sediments from the West Mebon", BEFEO 92, pp. 497-521. 
Polkinghorne, Martin, Brice Vincent, Nicolas Thomas \& David Bourgarit

2014 "Casting for the King: the Royal Palace bronze workshop of Angkor Thom", BEFEO 100, pp. 327-358.

ReEdy, Chandra L. \& Pieter Meyers

2007 "New methods for analyzing thin sections of casting core materials: a case study with Southeast Asian bronzes", in J.G. DougLAS, P. JETT \& J. WINTER (eds.), Scientific research on the sculptural arts of Asia: proceedings of the Third Forbes Symposium at the Freer Gallery of Art, London, Archetype Publications, pp. 103-114.

Robcis, Dominique, Sophie Descamps-Lequime, Nathalie Pingaud

\& Benoît MiLLE

2017 "Dorure et redorure de la statuaire antique en bronze: une nouvelle lecture de l'Apollon de Lillebonne", Technè 45, pp. 101-113.

Rolland, Pauline

2017 "La matière et le message. Albert France-Lanord (1915-1993) et la restauration des antiquités métalliques", Unpublished research paper, Paris, École du Louvre.

UnTRACHT, Oppi

1985 Jewelry: concepts and technology, London, Robert Hale.

VINCENT, Brice

2012 "Samrit. Étude de la métallurgie du bronze dans le Cambodge angkorien (fin du XI ${ }^{\mathrm{e}}$ - début du XIII ${ }^{\mathrm{e}}$ siècle)", Unpublished Ph.D. Thesis, Paris, Université Sorbonne Nouvelle - Paris 3, 3 vols.

2014a "Bronze metallurgy in Angkorian Cambodia (10th-13th c.): technical investigations on a selection of Khmer bronzes from the Metropolitan Museum of Art", Unpublished report, New York, Metropolitan Museum of Art.

2014b "Searching for the bronze workshops of Angkorian Cambodia: petrographic study applied to casting cores of 11th-12th c. Khmer bronzes", Unpublished report, Freer Gallery of Art and Arthur M. Sackler Gallery, Washington, D.C. 


\begin{tabular}{|c|c|c|c|c|c|c|c|c|c|c|c|}
\hline Designation & Acc. no. & Old acc. no. & $\begin{array}{c}\text { Reas- } \\
\text { sem- } \\
\text { bly }\end{array}$ & $\begin{array}{l}\text { H. } \\
\text { (cm) }\end{array}$ & $\begin{array}{l}\mathrm{L} . \\
(\mathrm{cm})\end{array}$ & $\begin{array}{l}\text { W. } \\
(\mathrm{cm})\end{array}$ & $\begin{array}{l}\text { th. } \\
(\mathrm{cm})\end{array}$ & $\begin{array}{l}\text { Weight } \\
\text { (kg) }\end{array}$ & $\begin{array}{l}\text { Tech- } \\
\text { nical } \\
\text { study }\end{array}$ & $\begin{array}{c}\text { ICP- } \\
\text { AES } \\
\text { (total) }\end{array}$ & $\begin{array}{c}\text { ICP- } \\
\text { AES } \\
\text { (year) }\end{array}$ \\
\hline Bust & ga 5387 & $\begin{array}{c}\text { 5456, E.1229, } \\
\text { E/I } 30,17\end{array}$ & $\mathrm{~N}$ & 123 & 222 & 72.5 & - & - & $01 / 2018$ & 6 & 2018 \\
\hline $\begin{array}{l}\text { Fragment of left } \\
\text { hip and thigh with } \\
\text { sampot and belt }\end{array}$ & ga 2084.1 & $\begin{array}{c}\text { 5457, E. } 1230 \mathrm{~A} \\
\text { E/I } 30,18\end{array}$ & \multirow{4}{*}{ Y } & - & $100^{*}$ & - & - & - & $01 / 2018$ & 2 & 2018 \\
\hline $\begin{array}{l}\text { Fragment with } \\
\text { pendants }\end{array}$ & ga 2988.1 & $\begin{array}{l}\text { 5457, E.1230D- } \\
\text { E, E/I } 30,18\end{array}$ & & - & 29 & 28 & 5.5 & - & $01 / 2018$ & 2 & 2015 \\
\hline $\begin{array}{l}\text { Fragment with } \\
\text { pendant }\end{array}$ & ga 1171 & $?$ & & - & 11.5 & 6 & 2 & 0.5 & $01 / 2018$ & 1 & 2018 \\
\hline Undet. fragment & ga 2988.3 & $\begin{array}{c}\text { 5457, E.1230J, } \\
\text { E/I } 30,18\end{array}$ & & - & 13 & 7 & 0.7 & 0.3 & $01 / 2018$ & 1 & 2015 \\
\hline $\begin{array}{c}\text { Fragment of left } \\
\text { arm }\end{array}$ & ga 2084.2 & $\begin{array}{c}\text { 5457, E.1230B } \\
\text { E/I } 30,18\end{array}$ & \multirow{2}{*}{ Y } & - & $94 *$ & - & - & - & $01 / 2018$ & 3 & 2018 \\
\hline $\begin{array}{c}\text { Fragment of left } \\
\text { arm }\end{array}$ & ga 2988.9 & $\begin{array}{c}\text { 5457, E.1230B } \\
\text { E/I } 30,18\end{array}$ & & - & - & - & - & - & $01 / 2018$ & 1 & 2014 \\
\hline Undet. fragment & ga 1170 & $?$ & \multirow{3}{*}{$\mathrm{Y}$} & - & 39 & 12.5 & 4 & 4 & $01 / 2018$ & - & - \\
\hline Undet. fragment & ga 2988.7 & $\begin{array}{c}\text { 5457, E.1230I, } \\
\text { E/I 30,18 }\end{array}$ & & - & $15^{*}$ & - & - & - & $01 / 2018$ & - & - \\
\hline Undet. fragment & ga 2988.10 & $\begin{array}{c}\text { 5457, E.1230G, } \\
\text { E/I } 30,18\end{array}$ & & - & 21 & 9.5 & 3.5 & 1.5 & $01 / 2018$ & 1 & 2015 \\
\hline $\begin{array}{l}\text { Fragment of thigh } \\
\text { with sampot }\end{array}$ & ga 2988.4 & $\begin{array}{c}\text { 5457, E.1230C, } \\
\text { E/I } 30,18\end{array}$ & \multirow{3}{*}{$\mathrm{Y}$} & - & 49.5 & 32 & 1.5 & - & $01 / 2018$ & - & - \\
\hline $\begin{array}{l}\text { Fragment of thigh } \\
\text { with sampot }\end{array}$ & ga 2988.6 & $\begin{array}{c}\text { 5457, E.1230C, } \\
\text { E/I } 30,18\end{array}$ & & - & 16 & 24 & 1.5 & - & $01 / 2018$ & - & - \\
\hline $\begin{array}{l}\text { Fragment of thigh } \\
\text { with sampot }\end{array}$ & ga 2988.8 & $\begin{array}{c}\text { 5457, E. } 1230 \mathrm{C} \\
\text { E/I } 30,18\end{array}$ & & - & 22.5 & 17 & - & - & $01 / 2018$ & 2 & 2018 \\
\hline Undet. fragment & ga 1162 & $?$ & \multirow{2}{*}{ Y } & - & 22 & 8 & 2.5 & 1.9 & $01 / 2018$ & - & - \\
\hline Undet. fragment & ga 1166 & $?$ & & - & 33 & 17 & 3 & 4.5 & $01 / 2018$ & 1 & 2014 \\
\hline $\begin{array}{l}\text { Fragment with } \\
\text { ornament }\end{array}$ & ga 741 & $?$ & $\mathrm{~N}$ & - & 11.5 & 7 & 3 & 0.4 & $05 / 2018$ & 1 & 2018 \\
\hline Undet. fragment & ga 1129 & $?$ & $\mathrm{~N}$ & - & 32 & 18 & 4.5 & 8.2 & $05 / 2018$ & 2 & 2018 \\
\hline Undet. fragment & ga 1130 & $?$ & $\mathrm{~N}$ & - & 30 & 28 & 6 & - & $01 / 2018$ & 1 & 2018 \\
\hline Undet. fragment & ga 1141 & $?$ & $\mathrm{~N}$ & - & 13.5 & 6.5 & 3 & 3 & $01 / 2018$ & 1 & 2018 \\
\hline Undet. fragment & ga 1173 & $?$ & $?$ & - & 24 & 13 & 4.5 & 1.8 & $01 / 2018$ & 2 & 2018 \\
\hline Undet. fragment & ga 1174 & $?$ & $\mathrm{~N}$ & - & 17 & 10.5 & 3 & 0.9 & $01 / 2018$ & 1 & 2018 \\
\hline Undet. fragment & ga 1175 & $?$ & $\mathrm{~N}$ & - & 9.5 & 9 & 2 & 0.5 & $01 / 2018$ & 1 & 2018 \\
\hline Undet. fragment & ga 1188 & $?$ & $\mathrm{~N}$ & - & 9.5 & 4.5 & 4 & 0.4 & $05 / 2018$ & 1 & 2018 \\
\hline Undet. fragment & ga 1210 & $?$ & $\mathrm{~N}$ & - & 33.5 & 21 & 4.5 & 3.8 & $01 / 2018$ & 1 & 2018 \\
\hline Undet. fragment & ga 2988.5 & $?$ & $\mathrm{~N}$ & - & 27 & 15.5 & $0.6-0.9$ & 1.0 & $01 / 2018$ & 2 & 2015 \\
\hline Undet. fragment & ga 2988.11 & $\begin{array}{c}\text { 5457, E. } 1230 \mathrm{H} \\
\text { E/I } 30,18\end{array}$ & $\mathrm{~N}$ & - & $14.5^{*}$ & - & - & - & $01 / 2018$ & 1 & 2018 \\
\hline Undet. fragment & $\begin{array}{c}\text { West } \\
\text { Mebon } 1\end{array}$ & - & $\mathrm{N}$ & - & - & - & - & - & $01 / 2018$ & 1 & 2017 \\
\hline $\begin{array}{l}\text { Left hand } \\
\text { of statue }\end{array}$ & ga 5444 & $\begin{array}{c}\text { 4991, E.1117, } \\
\text { E/I 701,17 }\end{array}$ & $\mathrm{N}$ & - & 33.5 & 13 & 9 & 5.4 & $05 / 2018$ & 3 & 2018 \\
\hline $\begin{array}{l}\text { Right hand } \\
\text { of statue }\end{array}$ & ga 5447 & $\begin{array}{l}\text { 4990, E.1116, } \\
\text { E/I 301,2 }\end{array}$ & $\mathrm{N}$ & - & 23.5 & 19 & 10 & 4.8 & $05 / 2018$ & 2 & 2018 \\
\hline Fragment of ankle & ga 2685 & CA 7286 & $\mathrm{~N}$ & - & 17 & 17 & 9.5 & 3.6 & $07 / 2018$ & - & - \\
\hline
\end{tabular}

Table 1 - West Mebon bronze corpus under technical investigation. 


\begin{tabular}{|c|c|c|c|c|c|}
\hline Designation & Location & Acc. no. & Sample ID & Sampling & Casting \\
\hline Fragment with ornament & NMC & ga 741 & ga 741 & & primary cast \\
\hline \multirow{2}{*}{ Undet. fragment } & NMC & ga 1129 & ga $1129-1$ & smooth part & primary cast \\
\hline & & & ga $1129-2$ & very thick part & secondary cast? \\
\hline Undet. fragment & NMC & ga 1130 & ga 1130 & thick part & primary cast \\
\hline Undet. fragment & NMC & ga 1141 & ga 1141 & & primary cast \\
\hline Undet. fragment & NMC & ga 1166 & ga 1166 & break & primary cast \\
\hline Fragment with pendant & NMC & ga 1171 & ga 1171 & section & primary cast \\
\hline \multirow[t]{2}{*}{ Undet. fragment } & NMC & ga 1173 & ga $1173-1$ & section & repair patch \\
\hline & & & ga $1173-2$ & & primary cast \\
\hline Undet. fragment & NMC & ga 1174 & ga 1174 & & primary cast \\
\hline Undet. fragment & NMC & ga 1175 & ga 1175 & & primary cast \\
\hline Undet. fragment & NMC & ga 1188 & ga 1188 & thin and regular part & primary cast? \\
\hline Undet. fragment & NMC & ga 1210 & ga 1210 & section & primary cast \\
\hline \multirow{2}{*}{$\begin{array}{l}\text { Fragment of left hip and } \\
\text { thigh with sampot and belt }\end{array}$} & NMC & ga 2084.1 & ga $2084.1-1$ & section (under the belt) & primary cast \\
\hline & & & ga 2084.1-2 & right large protuberance & secondary cast? \\
\hline \multirow[t]{3}{*}{ Fragment of left arm } & NMC & ga 2084.2 & ga $2084.2-1$ & & primary cast \\
\hline & & & ga 2084.2-2 & long cast-on (side) & secondary cast (assembly?) \\
\hline & & & ga $2084.2-3$ & protuberance (edge) & secondary cast (assembly?) \\
\hline \multirow[t]{2}{*}{ Fragment with pendants } & NMC & ga 2988.1 & ga 2988.1-1 & & primary cast \\
\hline & & & ga 2988.1-2 & & secondary cast \\
\hline Undet. fragment & NMC & ga 2988.3 & ga 2988.3 & & primary cast \\
\hline \multirow[t]{2}{*}{ Undet. fragment } & NMC & ga 2988.5 & ga $2988.5-1$ & & primary cast \\
\hline & & & ga $2988.5-2$ & core flash & primary cast \\
\hline \multirow{2}{*}{$\begin{array}{l}\text { Fragment of thigh with } \\
\text { sampot }\end{array}$} & NMC & ga 2988.8 & ga 2988.8-1 & & primary cast \\
\hline & & & ga $2988.8-2$ & & repair patch \\
\hline Fragment of left arm & NMC & ga 2988.9 & ga 2988.9 & break & primary cast \\
\hline Undet. fragment & NMC & ga 2988.10 & ga 2988.10 & & primary cast \\
\hline Undet. fragment & NMC & ga 2988.11 & ga 2988.11 & & primary cast \\
\hline \multirow[t]{6}{*}{ Bust } & NMC & ga 5387 & ga $5387-1$ & upper right hand (little finger) & primary cast \\
\hline & & & ga $5387-2$ & lower right hand (little finger) & primary cast \\
\hline & & & ga $5387-4$ & back head & primary cast \\
\hline & & & ga $5387-5$ & left shoulder (edge) & primary or secondary cast? \\
\hline & & & ga 5387-6 & $\begin{array}{l}\text { left shoulder (largest protu- } \\
\text { berance) }\end{array}$ & secondary cast (assembly) \\
\hline & & & ga $5387-7$ & torso (left ribs, section) & primary cast \\
\hline Undet. fragment & EFEO & West Mebon 1 & West Mebon-1 & & primary cast \\
\hline \multirow[t]{3}{*}{ Left hand of statue } & NMC & ga 5444 & ga $5444-1$ & hand & primary cast \\
\hline & & & ga $5444-2$ & forearm fragment & primary cast \\
\hline & & & ga $5444-3$ & between hand and forearm & secondary cast (assembly) \\
\hline \multirow[t]{2}{*}{ Right hand of statue } & NMC & ga 5447 & ga $5447-1$ & hand & primary cast \\
\hline & & & ga 5447-2 & $\begin{array}{l}\text { forearm fragment? (inside } \\
\text { cylinder) }\end{array}$ & primary or secondary cast? \\
\hline
\end{tabular}

Table 2a - Bulk-metal elemental composition of the bust and fragments of the West Mebon Viṣnu, plus the two hands ga 5444 and ga 5447. Results in wt.\%. All analyses performed on drillings by ICP-AES at the C2RMF. 


\begin{tabular}{|c|c|c|c|c|c|c|c|c|c|c|c|}
\hline Angkor & Sn & $\mathbf{P b}$ & Ag & As & $\mathbf{A u}$ & $\mathbf{B i}$ & Co & $\mathrm{Fe}$ & $\mathbf{N i}$ & Sb & Se \\
\hline Y & 12.4 & 0.15 & 0.056 & 0.14 & 0.0048 & 0.0023 & 0.016 & 0.034 & 0.32 & 0.03 & 0.0023 \\
\hline $\mathrm{Y}$ & 8.4 & 11.6 & 0.096 & 0.76 & 0.0020 & 0.11 & 0.0044 & 0.0039 & 0.06 & 0.20 & 0.0023 \\
\hline Y & 8.4 & 10.4 & 0.096 & 0.80 & 0.0020 & 0.11 & 0.0044 & 0.014 & 0.06 & 0.20 & 0.0024 \\
\hline $\mathrm{Y}$ & 7.6 & 7.6 & 0.096 & 0.72 & 0.0027 & 0.10 & 0.012 & 0.056 & 0.14 & 0.18 & 0.0022 \\
\hline $\mathrm{Y}$ & 8.8 & 0.10 & 0.020 & 0.16 & 0.0007 & 0.0039 & 0.0072 & 0.044 & 0.23 & 0.015 & 0.0022 \\
\hline Y & 13 & 0.26 & 0.06 & 0.15 & 0.0048 & 0.0033 & 0.015 & 0.021 & 0.32 & 0.023 & nd \\
\hline Y & 13.2 & 0.21 & 0.088 & 0.19 & 0.0024 & 0.0048 & 0.06 & 0.52 & 0.40 & 0.044 & 0.0022 \\
\hline $\mathrm{Y}$ & 0.016 & 0.012 & 0.020 & 0.22 & 0.0004 & 0.002 & 0.40 & 1.8 & 0.84 & 0.026 & 0.0016 \\
\hline Y & 9.6 & 0.30 & 0.064 & 0.17 & 0.0052 & 0.0048 & 0.018 & 0.06 & 0.31 & 0.04 & 0.0024 \\
\hline $\mathrm{Y}$ & 11.6 & 0.11 & 0.056 & 0.12 & 0.0044 & 0.0028 & 0.006 & 0.031 & 0.31 & 0.033 & 0.0024 \\
\hline Y & 12 & 0.22 & 0.06 & 0.15 & 0.0084 & 0.0016 & 0.022 & 0.017 & 0.35 & 0.031 & 0.0024 \\
\hline Y & 11.6 & 0.072 & 0.06 & 0.12 & 0.0048 & 0.0026 & 0.006 & 0.024 & 0.31 & 0.034 & 0.0022 \\
\hline $\mathrm{Y}$ & 11.6 & 0.068 & 0.048 & 0.17 & 0.0031 & 0.0023 & 0.013 & 0.028 & 0.29 & 0.052 & 0.0022 \\
\hline $\mathrm{Y}$ & 11.6 & 0.13 & 0.06 & 0.14 & 0.0044 & 0.0024 & 0.011 & 0.024 & 0.29 & 0.036 & 0.0021 \\
\hline Y & 12.4 & 0.10 & 0.052 & 0.17 & 0.0026 & 0.0023 & 0.011 & 0.026 & 0.31 & 0.048 & 0.0025 \\
\hline $\mathrm{Y}$ & 12.8 & 0.06 & 0.08 & 0.14 & 0.0048 & 0.0025 & 0.01 & 0.018 & 0.30 & 0.04 & 0.0021 \\
\hline Y & 11.2 & 0.48 & 0.06 & 0.20 & 0.0048 & 0.0064 & 0.031 & 0.10 & 0.32 & 0.048 & 0.0024 \\
\hline $\mathrm{Y}$ & 9.6 & 0.13 & 0.056 & 0.16 & 0.0044 & 0.0032 & 0.018 & 0.06 & 0.26 & 0.038 & 0.0018 \\
\hline Y & 12 & 0.082 & 0.048 & 0.16 & 0.0042 & 0.0016 & 0.012 & 0.03 & 0.31 & 0.031 & 0.0012 \\
\hline Y & 8.3 & 4 & 0.088 & 0.42 & 0.011 & 0.051 & 0.041 & 0.18 & 0.26 & 0.081 & 0.0012 \\
\hline $\mathrm{Y}$ & 12 & 0.25 & 0.041 & 0.18 & 0.002 & 0.0061 & 0.094 & 1 & 0.46 & 0.031 & 0.0009 \\
\hline Y & 12 & 0.10 & 0.052 & 0.13 & 0.0051 & 0.0024 & 0.025 & 0.059 & 0.32 & 0.018 & 0.0011 \\
\hline Y & 11 & 0.18 & 0.047 & 0.12 & 0.0048 & 0.002 & 0.025 & 0.057 & 0.33 & 0.017 & 0.0017 \\
\hline $\mathrm{Y}$ & 9 & 0.078 & 0.047 & 0.12 & 0.0038 & 0.0015 & 0.016 & 0.04 & 0.28 & 0.027 & 0.0013 \\
\hline Y & 0.13 & 0.014 & 0.072 & 0.14 & 0.0011 & nd & 0.0036 & 0.014 & 0.31 & 0.022 & 0.0026 \\
\hline Y & 9.7 & 0.081 & 0.063 & 0.15 & 0.0058 & 0.0024 & 0.015 & 0.064 & 0.32 & 0.023 & 0.0003 \\
\hline $\mathrm{Y}$ & 9.8 & 0.13 & 0.057 & 0.16 & 0.0043 & 0.0029 & 0.021 & 0.074 & 0.31 & 0.024 & 0.0009 \\
\hline $\mathrm{Y}$ & 10 & 0.14 & 0.06 & 0.16 & 0.0048 & 0.0026 & 0.010 & 0.014 & 0.30 & 0.040 & 0.0024 \\
\hline Y & 9.2 & 1.4 & 0.056 & 0.22 & 0.0027 & 0.015 & 0.084 & 0.60 & 0.48 & 0.036 & 0.0022 \\
\hline $\mathrm{Y}$ & 11.2 & 1.24 & 0.052 & 0.23 & 0.0034 & 0.016 & 0.084 & 0.60 & 0.44 & 0.044 & 0.0032 \\
\hline Y & 10.4 & 0.18 & 0.052 & 0.15 & 0.0056 & 0.0023 & 0.016 & 0.032 & 0.30 & 0.039 & 0.0022 \\
\hline Y & 10.4 & 1.2 & 0.048 & 0.22 & 0.003 & 0.015 & 0.11 & 0.84 & 0.52 & 0.040 & 0.0018 \\
\hline $\mathrm{Y}$ & 11.2 & 3.4 & 0.12 & 0.35 & 0.0084 & 0.036 & 0.072 & 0.44 & 0.34 & 0.088 & 0.0024 \\
\hline $\mathrm{Y}$ & 13.2 & 0.12 & 0.052 & 0.17 & 0.0056 & 0.0032 & 0.012 & 0.017 & 0.30 & 0.048 & 0.0024 \\
\hline $\mathrm{Y}$ & 13 & 0.20 & 0.047 & 0.11 & 0.0035 & nd & 0.042 & 0.26 & 0.20 & 0.016 & 0.0019 \\
\hline $\mathrm{Y}$ & 8.4 & 0.036 & 0.008 & 0.064 & 0.0006 & 0.004 & 0.0034 & 0.038 & 0.0064 & 0.0064 & 0.013 \\
\hline Y & 9.2 & 1.52 & 0.10 & 0.27 & 0.06 & 0.018 & 0.088 & 0.60 & 0.44 & 0.06 & 0.0020 \\
\hline $\mathrm{Y}$ & 9.6 & 0.06 & 0.0088 & 0.08 & 0.0007 & 0.006 & 0.0044 & 0.052 & 0.0044 & 0.0076 & 0.019 \\
\hline Y & 5.6 & 0.52 & 0.12 & 0.20 & 0.039 & 0.0076 & 0.016 & 0.064 & 0.30 & 0.076 & 0.0025 \\
\hline $\mathrm{Y}$ & 8.4 & 1.92 & 0.072 & 0.25 & 0.044 & 0.023 & 0.068 & 0.44 & 0.34 & 0.052 & 0.006 \\
\hline
\end{tabular}




\begin{tabular}{|c|c|c|c|c|c|c|c|c|}
\hline Designation & Sample ID & Zn & $\mathbf{B a}$ & Cd & $\mathrm{Cr}$ & Ge & $\mathrm{Hg}$ & In \\
\hline Fragment with ornament & ga 741 & nd & nd & nd & 0.0006 & nd & nd & 0.0020 \\
\hline \multirow[t]{2}{*}{ Undet. fragment } & ga $1129-1$ & nd & nd & nd & 0.0003 & nd & nd & 0.0033 \\
\hline & ga $1129-2$ & nd & nd & nd & 0.0004 & nd & nd & 0.0040 \\
\hline Undet. fragment & ga 1130 & nd & nd & nd & 0.0005 & nd & nd & 0.0031 \\
\hline Undet. fragment & ga 1141 & nd & nd & nd & 0.0006 & nd & nd & 0.0023 \\
\hline Undet. fragment & ga 1166 & nd & nd & nd & nd & nd & nd & 0.0006 \\
\hline Fragment with pendant & ga 1171 & nd & nd & nd & 0.0004 & nd & nd & 0.0025 \\
\hline \multirow[t]{2}{*}{ Undet. fragment } & ga $1173-1$ & nd & nd & nd & 0.0003 & nd & nd & 0.0034 \\
\hline & ga $1173-2$ & nd & nd & nd & 0.0004 & nd & nd & 0.0022 \\
\hline Undet. fragment & ga 1174 & 0.0003 & nd & nd & 0.0010 & nd & nd & 0.0024 \\
\hline Undet. fragment & ga 1175 & nd & nd & nd & 0.0004 & nd & nd & 0.0023 \\
\hline Undet. fragment & ga 1188 & nd & nd & nd & 0.0008 & nd & nd & 0.0022 \\
\hline Undet. fragment & ga 1210 & nd & nd & nd & 0.0005 & nd & nd & 0.0020 \\
\hline \multirow{2}{*}{$\begin{array}{l}\text { Fragment of left hip and } \\
\text { thigh with sampot and belt }\end{array}$} & ga 2084.1-1 & nd & nd & nd & 0.0006 & nd & nd & 0.0019 \\
\hline & ga 2084.1-2 & nd & nd & nd & 0.0008 & nd & nd & 0.0018 \\
\hline \multirow[t]{3}{*}{ Fragment of left arm } & ga 2084.2-1 & nd & nd & nd & 0.0005 & nd & nd & 0.0023 \\
\hline & ga $2084.2-2$ & nd & nd & nd & 0.0005 & nd & nd & 0.0022 \\
\hline & ga 2084.2-3 & 0.0030 & nd & nd & 0.0006 & nd & nd & 0.0016 \\
\hline \multirow[t]{2}{*}{ Fragment with pendants } & ga 2988.1-1 & nd & nd & nd & nd & nd & nd & 0.0012 \\
\hline & ga $2988.1-2$ & nd & nd & nd & nd & nd & nd & 0.0021 \\
\hline Undet. fragment & ga 2988.3 & nd & nd & nd & nd & nd & nd & nd \\
\hline \multirow[t]{2}{*}{ Undet. fragment } & ga 2988.5-1 & nd & nd & nd & nd & nd & nd & 0.001 \\
\hline & ga $2988.5-2$ & nd & nd & nd & nd & nd & nd & 0.0012 \\
\hline \multirow{2}{*}{$\begin{array}{l}\text { Fragment of thigh with } \\
\text { sampot }\end{array}$} & ga 2988.8-1 & nd & nd & nd & 0.0006 & nd & nd & 0.0007 \\
\hline & ga 2988.8-2 & nd & nd & nd & 0.0007 & nd & nd & 0.0026 \\
\hline Fragment of left arm & ga 2988.9 & nd & nd & nd & 0.0004 & nd & nd & 0.0004 \\
\hline Undet. fragment & ga 2988.10 & nd & nd & nd & nd & nd & nd & 0.0015 \\
\hline Undet. fragment & ga 2988.11 & nd & nd & nd & 0.0004 & nd & nd & 0.0021 \\
\hline \multirow[t]{6}{*}{ Bust } & ga $5387-1$ & 0.0017 & nd & nd & 0.0004 & nd & nd & 0.0030 \\
\hline & ga $5387-2$ & 0.0037 & nd & nd & 0.0010 & nd & nd & 0.0056 \\
\hline & ga $5387-4$ & nd & nd & nd & 0.0005 & nd & nd & 0.0022 \\
\hline & ga 5387-5 & 0.006 & nd & nd & 0.0004 & nd & nd & 0.0028 \\
\hline & ga 5387-6 & 0.017 & nd & nd & 0.0004 & nd & nd & 0.0032 \\
\hline & ga $5387-7$ & nd & nd & nd & 0.0007 & nd & nd & 0.0026 \\
\hline Undet. fragment & West Mebon-1 & nd & nd & nd & 0.0014 & nd & nd & 0.0005 \\
\hline \multirow[t]{3}{*}{ Left hand of statue } & ga 5444-1 & nd & nd & nd & 0.0005 & nd & nd & 0.0023 \\
\hline & ga 5444-2 & 0.0068 & nd & nd & 0.0004 & nd & nd & 0.0027 \\
\hline & ga 5444-3 & nd & nd & nd & 0.0005 & nd & nd & 0.0020 \\
\hline \multirow[t]{2}{*}{ Right hand of statue } & ga 5447-1 & nd & nd & nd & 0.0005 & nd & nd & 0.0021 \\
\hline & ga $5447-2$ & 0.0006 & nd & nd & 0.0004 & nd & nd & 0.0028 \\
\hline
\end{tabular}

Table 2a-Continued. 


\begin{tabular}{|c|c|c|c|c|c|c|c|c|c|c|}
\hline Mg & Mn & Mo & $\mathbf{P}$ & $\mathbf{S}$ & $\mathrm{Te}$ & $\mathbf{T i}$ & $\mathbf{U}$ & $\mathbf{V}$ & W & $\begin{array}{c}\text { ICP-AES } \\
\text { (year) }\end{array}$ \\
\hline nd & 0.0006 & nd & nd & nd & 0.026 & nd & nd & nd & nd & 2018 \\
\hline nd & $\mathrm{nd}$ & $\mathrm{nd}$ & nd & 0.12 & 0.023 & nd & nd & nd & nd & 2018 \\
\hline nd & $\mathrm{nd}$ & nd & nd & 0.12 & 0.024 & nd & nd & nd & nd & 2018 \\
\hline nd & 0.0005 & nd & nd & nd & 0.028 & nd & $\mathrm{nd}$ & nd & nd & 2018 \\
\hline nd & 0.0002 & nd & nd & nd & 0.025 & nd & nd & nd & nd & 2018 \\
\hline nd & 0.0019 & nd & 0.004 & nd & 0.0041 & nd & nd & nd & nd & 2014 \\
\hline nd & 0.0002 & nd & nd & nd & 0.030 & nd & nd & nd & nd & 2018 \\
\hline nd & nd & 0.015 & nd & 0.16 & 0.035 & nd & nd & nd & nd & 2018 \\
\hline nd & 0.0008 & nd & nd & nd & 0.026 & nd & $\mathrm{nd}$ & nd & nd & 2018 \\
\hline nd & 0.0003 & 0.0056 & nd & nd & 0.029 & nd & $\mathrm{nd}$ & nd & nd & 2018 \\
\hline nd & 0.0009 & nd & 0.008 & nd & 0.029 & nd & nd & nd & nd & 2018 \\
\hline nd & 0.0002 & nd & nd & nd & 0.027 & nd & nd & nd & nd & 2018 \\
\hline nd & 0.0004 & nd & nd & nd & 0.025 & nd & nd & nd & nd & 2018 \\
\hline nd & 0.0005 & nd & nd & nd & 0.026 & nd & nd & nd & nd & 2018 \\
\hline nd & 0.0006 & nd & nd & nd & 0.026 & nd & nd & nd & nd & 2018 \\
\hline nd & 0.0002 & nd & nd & nd & 0.025 & nd & nd & nd & nd & 2018 \\
\hline nd & 0.0008 & nd & nd & nd & 0.025 & nd & nd & nd & nd & 2018 \\
\hline nd & 0.0001 & nd & 0.007 & nd & 0.027 & nd & nd & nd & nd & 2018 \\
\hline nd & 0.0001 & $\mathrm{nd}$ & 0.011 & nd & 0.0071 & nd & nd & nd & nd & 2015 \\
\hline nd & 0.0001 & nd & 0.011 & nd & 0.006 & nd & nd & nd & nd & 2015 \\
\hline nd & nd & 0.011 & nd & nd & nd & nd & nd & nd & nd & 2015 \\
\hline nd & 0.0004 & nd & nd & nd & 0.0064 & nd & nd & nd & nd & 2015 \\
\hline nd & 0.0008 & nd & 0.008 & nd & 0.0073 & nd & nd & nd & nd & 2015 \\
\hline nd & 0.0003 & 0.0011 & nd & nd & 0.028 & nd & nd & nd & nd & 2018 \\
\hline nd & 0.0002 & nd & 0.012 & nd & 0.028 & nd & nd & nd & nd & 2018 \\
\hline nd & 0.0002 & 0.0005 & 0.007 & nd & 0.0029 & nd & nd & nd & nd & 2014 \\
\hline nd & nd & nd & 0.002 & nd & 0.007 & nd & nd & nd & nd & 2015 \\
\hline nd & 0.0003 & $\mathrm{nd}$ & nd & nd & 0.026 & nd & nd & nd & nd & 2018 \\
\hline nd & nd & nd & nd & nd & 0.031 & nd & nd & nd & nd & 2018 \\
\hline nd & nd & nd & nd & nd & 0.031 & nd & nd & nd & nd & 2018 \\
\hline nd & 0.0010 & nd & nd & nd & 0.03 & nd & nd & nd & nd & 2018 \\
\hline nd & nd & nd & nd & 0.11 & 0.03 & nd & nd & nd & nd & 2018 \\
\hline nd & $\mathrm{nd}$ & nd & nd & 0.10 & 0.028 & nd & $\mathrm{nd}$ & nd & nd & 2018 \\
\hline nd & 0.0008 & nd & nd & nd & 0.028 & nd & nd & nd & nd & 2018 \\
\hline nd & 0.0022 & 0.0005 & 0.016 & nd & 0.004 & nd & nd & nd & nd & 2017 \\
\hline nd & nd & nd & nd & nd & 0.030 & nd & nd & nd & nd & 2018 \\
\hline nd & nd & nd & nd & 0.11 & 0.027 & nd & nd & nd & nd & 2018 \\
\hline nd & nd & nd & nd & nd & 0.028 & nd & nd & nd & nd & 2018 \\
\hline nd & 0.0006 & nd & nd & nd & 0.029 & nd & nd & nd & nd & 2018 \\
\hline nd & nd & nd & 0.008 & nd & 0.027 & nd & nd & nd & nd & 2018 \\
\hline
\end{tabular}




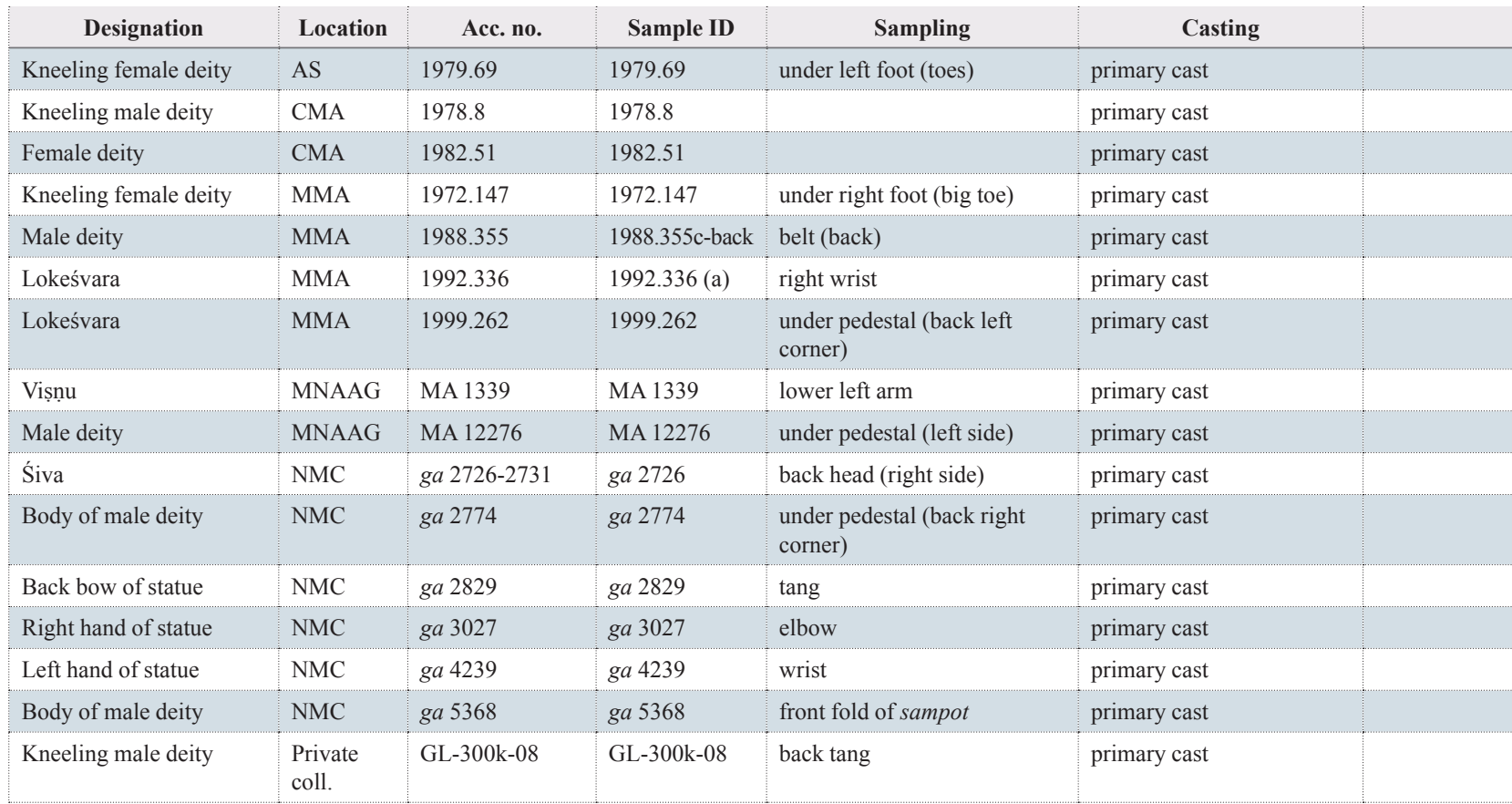

Table 2b - Bulk-metal elemental composition of 11th-century Khmer bronze statues. Results in wt.\%. All analyses performed on drillings by ICP-AES at the C2RMF.

\begin{tabular}{|c|c|c|c|c|c|c|c|c|}
\hline Designation & Sample ID & $\mathbf{Z n}$ & $\mathbf{B a}$ & Cd & $\mathrm{Cr}$ & Ge & $\mathrm{Hg}$ & In \\
\hline Kneeling female deity & 1979.69 & 0.38 & nd & nd & 0.003 & nd & nd & nd \\
\hline Kneeling male deity & 1978.8 & nd & nd & nd & 0.029 & nd & nd & nd \\
\hline Female deity & 1982.51 & nd & nd & nd & 0.0035 & nd & nd & nd \\
\hline Kneeling female deity & 1972.147 & nd & nd & nd & nd & nd & nd & 0.0006 \\
\hline Male deity & 1988.355c-back & 0.011 & nd & nd & nd & nd & nd & 0.0009 \\
\hline Lokeśvara & $1992.336(a)$ & 0.012 & nd & nd & nd & nd & nd & 0.0005 \\
\hline Lokeśvara & 1999.262 & 0.97 & nd & nd & nd & nd & nd & 0.0011 \\
\hline Viṣṇu & MA 1339 & 0.012 & nd & nd & nd & nd & nd & 0.0042 \\
\hline Male deity & MA 12276 & 0.0008 & nd & nd & 0.0002 & nd & nd & 0.0016 \\
\hline Śiva & ga 2726 & nd & nd & nd & 0.0009 & nd & nd & 0.0013 \\
\hline Body of male deity & ga 2774 & 0.0038 & nd & nd & nd & nd & nd & 0.0003 \\
\hline Back bow of statue & ga 2829 & nd & nd & nd & 0.0003 & nd & nd & 0.001 \\
\hline Right hand of statue & ga 3027 & nd & nd & nd & nd & nd & nd & 0.0007 \\
\hline Left hand of statue & ga 4239 & nd & nd & nd & nd & nd & nd & 0.0005 \\
\hline Body of male deity & ga 5368 & nd & nd & nd & nd & nd & nd & 0.0004 \\
\hline Kneeling male deity & GL-300k-08 & 0.037 & nd & nd & nd & nd & nd & 0.0004 \\
\hline
\end{tabular}

Table 2b-Continued. 


\begin{tabular}{|c|c|c|c|c|c|c|c|c|c|c|c|}
\hline Angkor & Sn & $\mathbf{P b}$ & Ag & As & $\mathbf{A u}$ & $\mathbf{B i}$ & Co & $\mathrm{Fe}$ & $\mathbf{N i}$ & Sb & Se \\
\hline $\mathrm{N}$ & 4.9 & 0.32 & 0.013 & 0.10 & nd & 0.018 & 0.095 & 0.33 & 0.054 & 0.0083 & 0.008 \\
\hline $\mathrm{N}$ & 9.6 & 0.098 & 0.067 & 0.18 & nd & 0.03 & 0.19 & 0.12 & 0.30 & 0.041 & 0.0064 \\
\hline $\mathrm{N}$ & 7.2 & 0.008 & 0.012 & 0.34 & 0.013 & 0.024 & 0.31 & 0.066 & 0.22 & 0.0032 & 0.0059 \\
\hline $\mathrm{N}$ & 7.3 & 0.35 & 0.025 & 0.19 & 0.021 & 0.0034 & 0.24 & 0.67 & 0.23 & 0.0034 & nd \\
\hline $\mathrm{N}$ & 12 & 1.6 & 0.11 & 0.30 & 0.038 & 0.017 & 0.061 & 0.29 & 0.25 & 0.064 & 0.0005 \\
\hline $\mathrm{N}$ & 10 & 0.46 & 0.16 & 0.61 & 0.01 & 0.0081 & 0.017 & 0.17 & 0.059 & 0.21 & 0.002 \\
\hline $\mathrm{N}$ & 9.3 & 2.5 & 0.31 & 0.30 & 0.0095 & 0.0079 & 0.019 & 0.12 & 0.068 & 0.076 & 0.0019 \\
\hline $\mathrm{N}$ & 12 & 0.43 & 0.096 & 0.17 & 0.018 & 0.0075 & 0.026 & 0.10 & 0.21 & 0.026 & 0.0024 \\
\hline $\mathrm{N}$ & 7.9 & 2.2 & 0.23 & 1.3 & 0.018 & 0.066 & 0.012 & 0.054 & 0.059 & 0.12 & 0.0015 \\
\hline $\mathrm{Y}$ & 11 & 0.24 & 0.015 & 0.29 & nd & 0.0036 & 0.17 & 0.49 & 0.35 & 0.024 & nd \\
\hline $\mathrm{Y}$ & 9.3 & 0.28 & 0.14 & 0.17 & 0.15 & 0.0053 & 0.021 & 0.085 & 0.12 & 0.02 & 0.0097 \\
\hline Y & 10 & 0.068 & 0.031 & 0.19 & 0.0051 & 0.0044 & 0.036 & 0.077 & 0.27 & 0.023 & 0.0078 \\
\hline $\mathrm{N}$ & 10 & 0.038 & 0.037 & 0.16 & nd & 0.0026 & 0.061 & 1.2 & 0.25 & 0.012 & nd \\
\hline $\mathrm{N}$ & 10 & 0.031 & 0.038 & 0.18 & nd & 0.0029 & 0.047 & 0.83 & 0.24 & 0.012 & nd \\
\hline Y & 11 & 0.15 & 0.034 & 0.15 & 0.0044 & 0.0031 & 0.013 & 0.015 & 0.38 & 0.014 & 0.0011 \\
\hline $\mathrm{N}$ & 4.5 & 0.15 & 0.076 & 0.19 & 0.0051 & 0.0028 & 0.039 & 0.05 & 0.20 & 0.021 & nd \\
\hline
\end{tabular}

\begin{tabular}{|c|c|c|c|c|c|c|c|c|c|c|}
\hline Mg & Mn & Mo & $\mathbf{P}$ & $\mathbf{S}$ & $\mathrm{Te}$ & $\mathbf{T i}$ & $\mathbf{U}$ & $\mathbf{V}$ & W & $\begin{array}{c}\text { ICP-AES } \\
\text { (year) }\end{array}$ \\
\hline nd & 0.0072 & nd & 0.069 & nd & nd & nd & nd & nd & nd & 2014 \\
\hline nd & 0.0014 & nd & 0.014 & nd & 0.0023 & nd & nd & nd & nd & 2014 \\
\hline nd & 0.0004 & nd & nd & nd & 0.019 & nd & nd & nd & nd & 2014 \\
\hline nd & nd & nd & nd & 0.20 & 0.0065 & nd & nd & nd & nd & 2014 \\
\hline nd & nd & 0.0004 & nd & 0.003 & 0.0028 & nd & nd & nd & nd & 2014 \\
\hline nd & nd & nd & nd & 0.012 & 0.0037 & nd & nd & nd & nd & 2014 \\
\hline nd & nd & nd & nd & nd & 0.0053 & nd & nd & nd & nd & 2014 \\
\hline nd & nd & nd & nd & 0.015 & 0.0058 & nd & nd & nd & nd & 1999 \\
\hline nd & nd & nd & 0.029 & 0.043 & nd & nd & nd & nd & nd & 2011 \\
\hline nd & 0.0012 & 0.0009 & 0.010 & nd & 0.012 & nd & nd & nd & nd & 2014 \\
\hline nd & 0.0002 & nd & 0.003 & nd & 0.0031 & nd & nd & nd & nd & 2014 \\
\hline nd & 0.0047 & 0.0005 & 0.007 & nd & 0.0035 & nd & nd & nd & nd & 2014 \\
\hline nd & nd & 0.0003 & 0.022 & nd & 0.0039 & nd & nd & nd & nd & 2014 \\
\hline nd & nd & 0.0002 & nd & nd & 0.0041 & nd & nd & nd & nd & 2014 \\
\hline nd & nd & 0.0006 & nd & nd & 0.0042 & nd & nd & nd & nd & 2014 \\
\hline nd & 0.0006 & nd & nd & nd & 0.0037 & nd & nd & nd & nd & 2014 \\
\hline
\end{tabular}

